\title{
A Review of SERS for Biomaterials Analysis Using Metal Nanoparticles
}

\author{
Eue-Soon Jang \\ Department of Applied Chemistry, Kumoh National Institute of Technology, \\ Gumi, 39177, Republic of Korea \\ 바이오 물질 분석을 위한 금속 나노입자를 이용한 SERS 분석 연구동향 \\ 장의순 \\ 금오공과대학교 응용화학과
}

(Received September 6, 2019; Accepted September 10, 2019)

\begin{abstract}
:
Surface enhanced Raman scattering (SERS) was first discovered in 1974 by an unexpected Raman signal increase from Pyridine adsorbed on rough Ag electrode surfaces by the M. Fleishmann group." M. Moskovits group suggested that this phenomenon could be caused by surface plasmon resonance (SPR), which is a collective oscillation of free electrons at the surface of metal nanostructures by an external light source. ${ }^{2-14)}$ After about 40 years, the SERS study has attracted great attention as a biomolecule analysis technology, and more than 2500 new papers and 500 review papers related to SERS topic have been published each year in recently. ${ }^{15)}$ The advantages of biomaterials analysis using SERS are as follows; (1) Molecular level analysis is possible based on unique fingerprint information of biomolecule, ${ }^{16-20)}$ (2) There is no photo-bleaching effect of the Raman reporters, allowing long-term monitoring of biomaterials compared to fluorescence microscopy, (3) SERS peak bandwidth is approximately 10 to 100 times narrower than fluorescence emission from organic phosphor or quantum dot, resulting in higher analysis accuracy, ${ }^{21)}$ 22) (4) Single excitation wavelength allows analysis of various biomaterials, (5) By utilizing near-infrared (NIR) SERSactivated nanostructures and NIR excitation lasers, auto-fluorescence noise in the visible wavelength range can be avoided from in vivo experiment and light damage in living cells can be minimized compared to visible lasers, (6) The weak Raman signal of the water molecule makes it easy to analyze biomaterials in aqueous solutions. For this reason, SERS is attracting attention as a next-generation non-invasive medical diagnostic device as well as substance analysis. In this review, the principles of SERS and various biomaterial analysis principles using SERS analysis will be introduced through recent research papers.
\end{abstract}

Keywords : SERS, Hot-spots, Raman reporter-labeled SERS analysis, Label-free SERS analysis 


\section{특 집 ㅁㅃ 장의순}

\section{1. 서론}

Surface enhanced Raman scattering(SERS) 현상 은 1974년 M. Fleishmann 그룹에 의하여 거친 $\mathrm{Ag}$ 전극 표면에 흡착된 Pyridine으로부터 예상치 못했던 라만 신 호 증가로 처음으로 발견되었다.1) 이러한 현상은 $\mathrm{M}$. Moskovits등에 의하여 외부 광원에 의한 금속 나노구조 체 표면에서 자유전자들의 집단 진동(Collective oscillations)인 Surface plasmon resonance(SPR)에 의해 기원할 수 있음이 제시 되었다. ${ }^{2-14)}$ 이후 약 40 년의 연구개발을 통해 SERS는 생체분자 분석기술로써 크게 주목받고 있다. 최근에 SERS와 관련된 신규 논문은 약 2500편/년 이상 발표되고 있으며 SERS 및 관련 주제에 대한 리뷰 논문은 약 500편/년 이상이 나오고 있는 점을 고려하면 SERS 연구가 얼마나 활발히 진행되고 있는가 를 알 수 있다. ${ }^{15)} \mathrm{SERS}$ 를 이용한 생체 물질 분석법의 장 점들은 다음과 같다; (1) 바이오 분자들의 고유한 지문정 보(Fingerprint information)를 바탕으로 분자 수준의 분석이 가능, ${ }^{16-20)}$ (2) 유기 형광체의 광분해 문제점이 없 기 때문에 형광현미경 분석법과 비교하여 장시간 모니터 링이 가능, (3) 유기형광체나 양자점의 형광 발광보다 SERS 피크 대역폭(peak bandwidth)이 약 10 100배
나 좁아 분석 정확도가 높음, ${ }^{21,}$ 22) (4) 단일 여기 파장 (Single excitation wavelength)으로 다양한 물질의 분 석이 가능, (5) 근적외선 SERS 활성 나노구조체 및 근적 외선 여기 레이저를 활용함으로써 생체에서 발생하는 가 시광선 파장대의 자체형광(Auto-fluorescence) 노이즈 를 피하고 가시광선 레이저와 비교하여 살아있는 세포들 의 광 손상을 최소화 할 수 있음, (6) 물 분자의 라만 신호 가 미약하기 때문에 수용액에 존재하는 바이오 물질들을 손쉽게 분석할 수 있음. 이러한 이유 때문에 SERS는 물 질 분석뿐만 아니라 차세대 비침습적 의학 진단장비로도 주목받고 있다. 본 리뷰에서는 SERS의 원리 및 이를 이 용한 다양한 생체물질 분석 원리 등을 최근 연구결과들을 통해서 소개하고자 한다.

\section{2. 본론}

\subsection{SERS 효과}

빛이 어떤 매질을 통과할 때, 빛의 일부는 산란되어 진 행방향에서 벗어나 다른 방향으로 진행하는데 이때 원래 의 에너지를 그대로 유지하면서 산란되는 과정을 레일리 탄성 산란(Rayleigh elastic scattering)이라 하고 에너 지를 잃거나 얻으면서 산란되는 과정을 라만 비탄성 산란
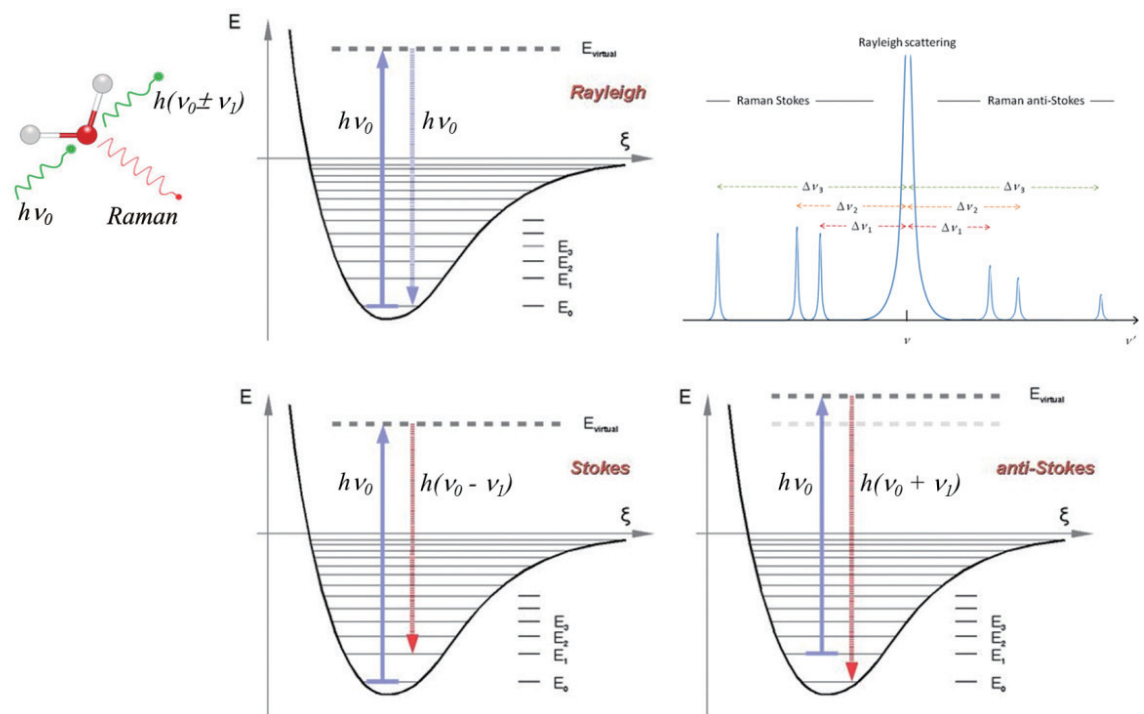

그림 1. Rayleigh scattering, Raman stokes scattering, 및 Raman anti-stokes scattering에 대한 모식도 
(Raman inelastic scattering)이라 한다. 23), 24) 라만 비탄 성 산란에서 라만 활성 분자가 빛을 흡수하여 진동에너지 (Vibrational energy)가 증가되면 산란된 빛의 에너지가 감소하면서 파장이 길어지게 되는데 이를 Stokes 효과라 한다. ${ }^{23)}{ }^{24)}$ 반대로 라만 활성 분자가 빛을 흡수하여 진동 에너지를 방출하면서 산란된 빛의 파장이 짧아지는 효과 를 Anti-stokes 효과라 한다(그림 1). ${ }^{23), 24)}$ 라만 비탄성 산란을 통해 방출되는 에너지는 분자 구조와 밀접한 관계 에 있으며 라만 활성 분자들 마다 진동모드의 고유한 지 문 정보가 나타나기 때문에 이를 분석하면 분자구조를 확 인할 수 있다.

$\mathrm{k}$ 번째 진동 모드의 Stokes band와 Anti-stokes band 사이의 단면 비(Cross-section ratio, $\left.\mathrm{r}_{\mathrm{k}}{ }^{\mathrm{as} / \mathrm{s}}=\mathrm{S}_{\mathrm{k}}{ }^{\mathrm{as}} / \mathrm{S}_{\mathrm{k}}{ }^{\mathrm{s}}\right)$ 는 기저 준위(Ground state)와 첫번째 진동 전이 준위( $\left(1^{\text {st }}\right.$ vibrational excitation state)에 분포하는 전자들의 밀도 에 비례하며 기저 진동 준위에 존재하는 전자들의 분포가 더 크기 때문에 일반적으로 라만 스펙트럼에서 Stokes band가 Anti-stokes band와 비교하여 월등히 강하게 나 타난다. ${ }^{24-27)}$ 예를 들면, 상온에서 여기 레이저의 파수 $\left(\mathrm{n}_{0}\right)$ 가 $20,000 \mathrm{~cm}^{-1}(514.5 \mathrm{~nm}), \mathrm{k}$ 번째 진동 모드의 Raman

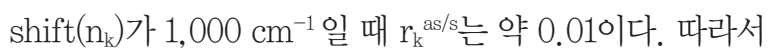
라만 활성 분자에 의해 생성되는 라만 신호는 주로 Stokes band에 의한 것이며 이는 다음과 같다. ${ }^{24-27)}$

$$
P_{\text {Raman }}=K N S_{k} I
$$

$-P_{\text {Raman }}($ photons $/ \mathrm{s})$ : 광자 카운터 검출기(Photon counter detector)에 의해 측정된 라만 파워

$-K$ : 분자로부터 방출된 광자들을 광자 카운터 검출 기에 의해서 전자로 변환된 상수 값

$-N$ : 여기 레이저에 노출된 분자의 수

$-\sigma_{\mathrm{k}}\left(\mathrm{cm}^{2} / \mathrm{molecule}\right): k$ 번째 진동 모드의 라만 횡단면

- I(photons $\left./\left(\mathrm{cm}^{2} \cdot \mathrm{s}\right)\right)$ : 여기 레이저 세기

그러나 표 1에 나타낸 바와 같이 형광 방출과 비교하여 라만 산란은 활성 분자들의 단면적이 약 $10^{10}$ 배나 작기 때 문에 라만 신호가 매우 미약하다는 단점이 있다. ${ }^{28)}$

만일, 라만 활성 분자가 적절한 나노 구조체의 표면에 존 재한다면 라만 산란은 강하게 증폭될 수 있으며 이를 Surface enhanced Raman scattering(SERS)이라고 한다. $\mathrm{SERS}$ 파워 $\left(\mathrm{P}_{\mathrm{SERS}}\right)$ 는 다음 식과 같이 전자기적 증폭 $\left(\mathrm{G}_{\mathrm{SERS}}^{\mathrm{Em}}\right)$ 과 화학적 증폭 $\left(\mathrm{G}_{\mathrm{SERS}}^{\mathrm{Chem}}\right)$ 으로 나타낼 수 있다. ${ }^{29)}$

$$
\begin{aligned}
& P_{S E R S}=G_{S E R S} P_{R a m a n}=G_{S E R S}^{E m} G_{S E R S}^{C h e m} P_{\text {Raman }} \\
& {\left[\begin{array}{l}
G_{S E R S}: \text { Total SERS enhancement factor } \\
G_{S E R S}^{E m}: \text { Electromagnetic enhancement factor } \\
G_{S E R M}^{C h e m}: \text { Chemical enhancement factor }
\end{array}\right.}
\end{aligned}
$$

전자기적 증폭(Electric field enhancement)의 특징 은 다음과 같다.

- 나노구조체 표면에조사된 빛의국소화(Localization) 에 의한 효과로 나노 구조체의 전형적인 특징이며 분 자 유형과 무관하다.

(a)

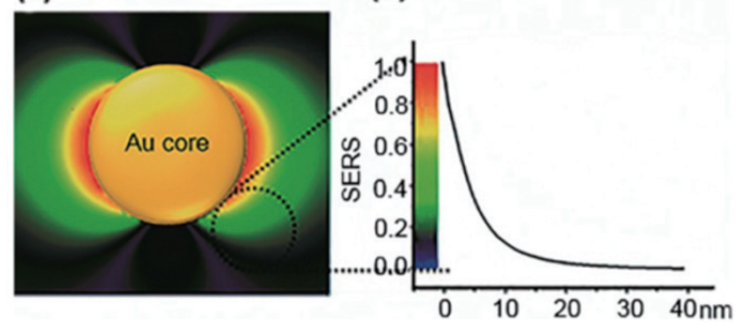

그림 2. (a) 여기 레이저에 의한 Gold 나노입자 표면에서 전기장 증 폭의 Finite difference time domain, (b) Gold 나노입자 표 면에서 거리에 따른 SERS 효과 변화 (출처: 참고문헌 30)

표 1. 라만 산란과 형광 방출의 분자 단면적 비교. (출처 : 참고문헌 28)

\begin{tabular}{clc}
\hline Type & \multicolumn{1}{c}{ Process } & Cross-section $\left(\mathrm{cm}^{2}\right)$ of molecule \\
\hline UV & Absorption & $10^{-18}$ \\
IR & Absorption & $10^{-21}$ \\
Fluorescence & Emission & $10^{-19}$ \\
Rayleigh & Elastic scattering & $10^{-26}$ \\
Raman & inelastic scattering & $10^{-29}$ \\
\hline
\end{tabular}


표 2. 전자기적 증폭과 화학적 증폭 값의 비교. (출처 : 참고문헌 29)

\begin{tabular}{|c|c|c|}
\hline $\mathrm{G}_{\mathrm{SERS}}$ & Approximate max. value & Note \\
\hline $\mathrm{G}_{\mathrm{SERS}}^{\mathrm{EM}}$ & $10^{8}$ & Averaged over the substrate ${ }^{32), 33)}$ \\
\hline $\mathrm{G}^{\mathrm{EM}} \mathrm{SERS}_{\mathrm{S}}$ & $10^{10}$ & In a hot spot ${ }^{34)}$ \\
\hline$G^{\text {Chem }_{\text {SERS }}}$ & $10^{2}$ & Atomic scale roughness $\left.\left.{ }^{3)}, 32\right), 35-36\right)$ \\
\hline $\mathrm{G}^{\mathrm{Chem}_{\text {SERS }}}$ & $10^{4}$ & Charge transfer resonance ${ }^{37)}$ \\
\hline
\end{tabular}

- 증폭 효과가 $10^{8} \sim 10^{10}$ 으로 SERS에 가장 큰 기여를 한다.

- 분자가 나노 구조체 표면에서 $1 \sim 10 \mathrm{~nm}$ 이내에 존재 해야 하며 거리가 증가할수록 증폭 효과는 감소한다. 반면에 화학적 증폭(Chemical enhancement)의 특징 은 다음과 같다.

- 기판과의 물리-화학적 상호작용의 결과로써 분자의 분극성(진동 모드의 라만 횡단면)의 변형으로부터 발 생하며 분자 유형에 따라 다르다.

- 증폭 효과가 $10^{2} \sim 10^{4}$ 으로 전자기적 증폭에 비하여 $\mathrm{SERS}$ 기여도가 작다.

- 화학적 증폭이 발생하기 위해서는 분자는 기판 표면
으로부터 수 옹스트롱 $(\AA)$ 이내에 존재해야 한다. 대략적인 전자기적 증폭과 화학적 증폭 값은 표 2 와 같다. ${ }^{30),}{ }^{31)}$

일반적으로 화학적 증폭은 전자기적 증폭 효과에 비해 $\mathrm{SERS}$ 기여가 미미하며 단거리 효과이기 때문에 SERS 효과는 전자기적 증폭 효과만을 고려한다. 그림 3은 금속 나노입자 사이에 존재하는 피리딘(Pyridine) 분자의 전 자기적 증폭에 의한 SERS 효과를 보여주고 있다. ${ }^{30), ~}{ }^{38)}$

입사 레이저가 금속 나노 구조체와 유전체 계면에 충돌 할 때 입사광의 주파수가 금속의 자유전자 고유 진동 주 파수와 일치하면 빛의 전자기파는 자유전자들의 집단 진 동을 유도할 수 있으며 이를 표면 플라즈몬 공명(Surface

(a)

(b) LSPR

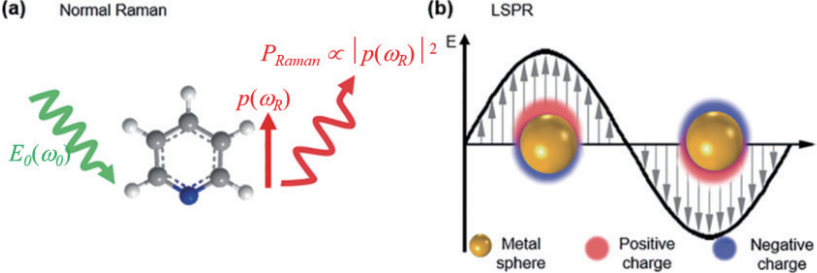

(c) SERS

First step: $\left.G_{1} \approx\left|E_{b c}\left(\omega_{0}\right)\right| E_{0}\left(\omega_{0}\right)\right|^{2}$

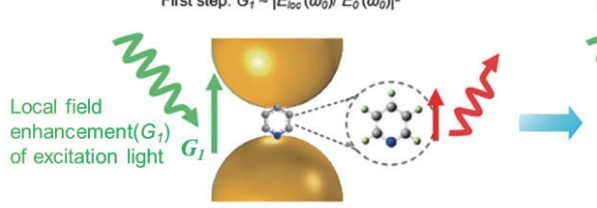

Second step: $G_{2} \approx \mid E_{b o}\left(\omega_{a}\right) / E_{0}\left(\omega_{B}\right)^{2}$

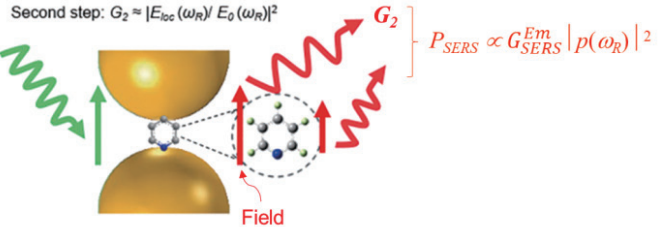

$E_{0}\left(\omega_{0}\right)$ : external electric field oscillating at the laser(angular) frequency $\left(\omega_{0}\right)$

$p\left(\omega_{R}\right): E_{0}\left(\omega_{0}\right)$ induced molecular dipole oscillating at Raman frequency $\left(\omega_{R}\right)$

enhancement $\left(G_{2}\right)$ of

$P_{\text {Raman }}:$ Raman power

$G_{1}$ : locally enhanced electric field of excitation laser by the plasmonic substrate

$G_{2}: G_{1}$ induced Raman enhancements of molecular dipole

그림 3. (a) 일반적인 라만; 각 주파수 $w_{L}$ 에서 진동하는 전기장 $\left(E_{d}\left(w_{L}\right)\right)$ 을 갖는 입사 레이저가 피리딘 분자에 충돌하면 고유 라만 주파수 $\left(p\left(w_{L}\right)\right)$ 에서 진동하는 쌍극자가 유도된다. 이때, 쌍극자에 의해 방출되는 라만 파워는 라만 주파수의 제곱에 비례한다. (b) 빛의 전자기파에 의해 유도된 금속 나노 구조체의 SPR 효과; 금속의 자유전자 고유 진동 주파수에 해당하는 입사 광에 의해 자유전자들의 집단 진동 이 유도되며 이때 자유전자들은 빛의 전기장의 반대방향으로 진동하게 된다. (c) SERS에서 전자기파 증폭 메커니즘에 대한 모식도. (출처: 참고문헌 30,38 ) 

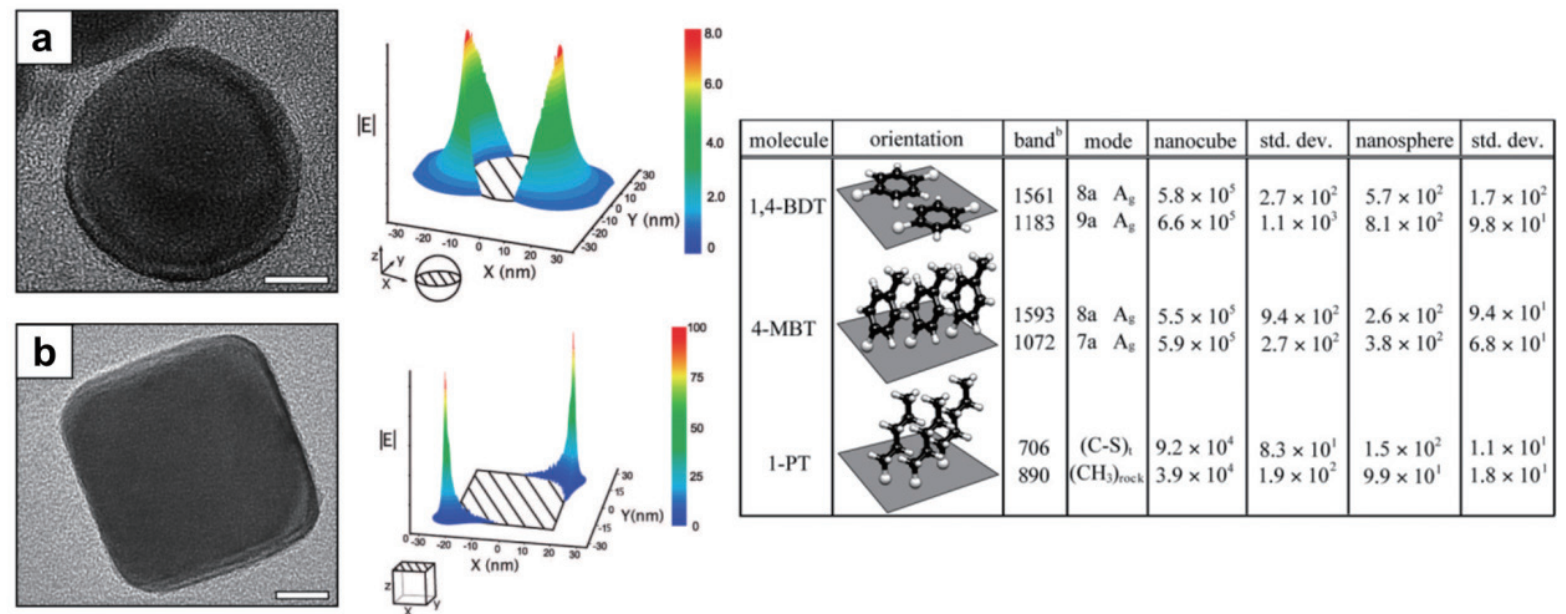

그림 4. (a) 구형, (b) 큐브형 Ag 나노입자의 TEM 사진 및 전기장 증폭 시뮬레이션 계산 결과, 및 각 나노입자에 의한 1, 4-benzenedithiol(1,4$\mathrm{BDT}), 4-$ methylbenzenethiol(4-MBT), 1-pentanethiol(1-PT)의 SERS 효과. (출처 : 참고문헌 46)

plasmon resonance)라고 한다. ${ }^{7)} \mathrm{SPR}$ 주파수는 입자의 크기, 모양, 유전체 환경, 전자 밀도, 유효 전자의 질량 등 에 의존한다. 금속 나노구조체에서 SPR은 특정 위치에 고도로 국한될 수 있는데 이를 Localized SPR(LSPR)이 라 하며 이러한 영역을 Hot-spot area이라고 한다. 이 러한 강한 LSPR 효과를 갖는 나노입자들을 플라즈모닉 나노입자(Plasmonic nanoparticles)라고 하며 $\mathrm{Ag}, \mathrm{Au}$, $\mathrm{Cu}$ 등이 있다. 라만 활성 분자가 플라즈모닉 나노 구조체 표면 가까이 Hot-spots에 위치하면 SERS 효과가 발생 한다. 이때, 라만 신호는 그림 3 (c)와 (d)에서 나타낸 바 와 같이 2 단계로 증폭된다. ${ }^{29), 38)}$ 첫번째 증폭 과정은 여 기 파장에서 나노 구조체 주변의 국소장의 증폭(Local field enhancement)이다. 각 주파수 $W_{L}$ 에서 진동하는 전기장 $\left(E_{0}\left(w_{L}\right)\right)$ 을 갖는 여기 레이저에 의해 증폭된 국소 장은 $E_{100}\left(W_{L}\right)=G_{1} E_{0}\left(W_{L}\right)$ 로 나타낼 수 있으며 $G_{\sqrt{\Gamma}}$ 은 근거 리 전자기장의 증폭 지수이다. 두번째 증폭 과정은 플라 즈모닉 나노 구조체가 안테나와 같이 증폭된 국소장을 라 만 활성 분자에 전달하면서 라만 신호가 증폭되는 과정이 다. 증폭된 국소장에 의한 증폭된 라만 신호는 $E_{l o c}\left(W_{R}\right)=$ $G_{2} E_{0}\left(W_{R}\right)$ 로 나타낼 수 있으며 $G_{2}$ 는 라만 증폭 지수이다. 따라서 금속 나노구조체의 전자기적 증폭에 의한 전체 SERS 효과 $\left(G^{E m_{S E R S}}\right)$ 는 $G_{1} \mathrm{x} G_{2}$ 로 나타낼 수 있다. 만일 Stokes 라만 주파수가 여기 레이저의 진동 주파수와 크
게 차이 나지 않는다면 $G_{1} \cong G_{2}$ 이며 따라서 SERS 증폭 계수는 국부 전기장 증폭의 4 제곱에 비례 $\left(G^{E m_{S E R S}} \cong\right.$ $\left.\left|E_{0}\left(W_{L}\right)\right|^{4}\right)$ 한다. ${ }^{31), 39)}$

\subsection{SERS Hot-spots}

플라즈모닉 나노 구조체 표면의 전자기장은 불균일하 게 분포하며 종종 날카로운 부위, 입자간 나노 갭 (Nanogaps), 입자-기판 사이의 나노 갭과 같이 공간적 으로 좁은 영역에 고도로 국한되며 이러한 영역을 SERS hot-spots이라고 한다.

\section{(1) 1 세대 SERS hot-spots}

1 세대 Hot-spots은 용매에 분산된 $\mathrm{Au}, \mathrm{Ag}$ 와 같은 단 일 나노물질로부터 생성된다. 일반적으로 Hot-spots은 날카로운 모서리 부분에 국한되어 증폭되는 특징이 있는 데 이로 인해 구형의 나노 입자 보다는 나노 큐브, 삼각 나노프리즘, 나노막대, 나노스타 등의 모양을 갖는 나노 구조체들에서 더 강한 SERS 효과를 기대할 수 있다. ${ }^{40-45)}$ 그림 3 은 $\mathrm{Ag}$ 구형 나노입자와 $\mathrm{Ag}$ 나노큐브의 표면에서 증폭된 전기장 $(E)$ 을 이론적으로 계산하여 시뮬레이션한 결과 및 3 가지 라만 활성 분자들의 SERS 신호 비교 결과 를 보여주고 있다. ${ }^{46)} \mathrm{Ag}$ 구형 나노입자와 비교하여 $\mathrm{Ag}$ 나노큐브의 모서리에서 전기장이 약 10 배 이상 강하게 증 


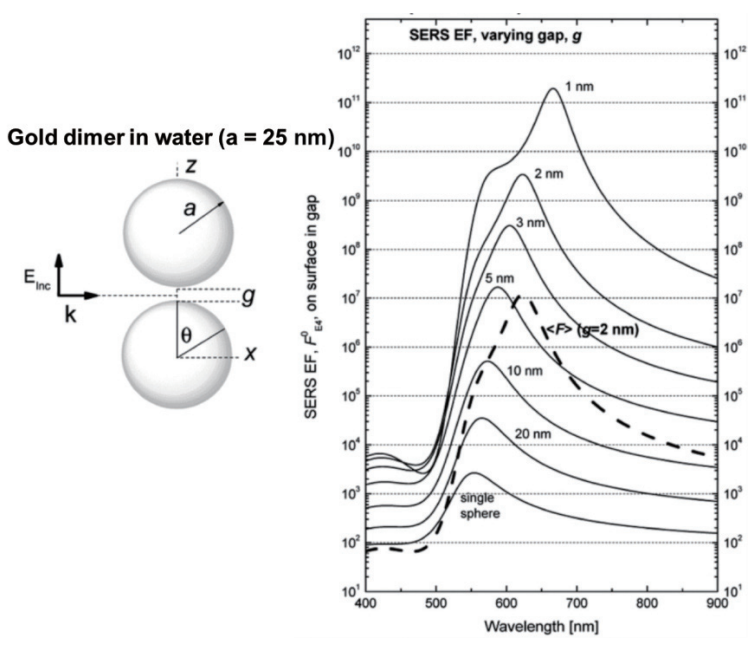

그림 5. 반지름이 $a$ 인 2개의 구형 Gold 나노입자들 사이 거리 $(\mathrm{g})$ 에 따른 SERS 변화에 대한 모식도 (출처 : 참고문헌 39)

폭되는 것을 확인할 수 있는데 앞서 언급한 바와 같이 $G^{E m_{S E R S}} \cong\left|E_{0}\left(W_{L}\right)\right|^{4}$ 이기 때문에 $\mathrm{Ag}$ 나노큐브에서 $\mathrm{SERS}$ 신호가 약 $10^{4}$ 배 증가할 것으로 예상할 수 있으며 실제로 $\mathrm{Ag}$ 나노큐브 표면에 존재하는 라만 활성 분자들 의 SERS 신호가 약 $10^{3}$ 배 증가한 것을 확인할 수 있다.

\section{(2) 2세대 SERS hot-spots}

2 세대 SERS hot-spots은 응집된 나노 구조체 어셈 블리로부터 발생하며 1세대 Hot-spots 보다 약 104배 증 폭된 SERS 효과를 나타낸다. 그림 4는 물에 분산된 25 $\mathrm{nm}$ 금 나노입자 이량체(dimer) 사이의 거리(gap, g)에 따른 SERS 효과를 보여주고 있으며 $\mathrm{g}$ 값이 $10 \mathrm{~nm}$ 에서 $1 \mathrm{~nm}$ 로 감소함에 따라 SERS 전기장이 $10^{5}$ 에서 $10^{9}$ 으로 크게 증가함을 보여주고 있다. ${ }^{39)}$ 금속 나노 구조체 이량 체에서 Hot-spots이 차지하는 면적은 약 $1 \%$ 보다 작지 만 전체 SERS 신호에서 Hot-spots에서 증폭된 SERS 신호가 약 $50 \%$ 이상 기여한다는 점을 고려한다면 Hotspots의 중요성을 짐작할 수 있다.

최근에는 Self-assembly 방법 및 Lithography 방법 등의 나노기술을 활용하여 그림 6 과 같이 금속 나노구조 체들의 어셈블리의 조절이 가능해지면서 2 세대 SERS Hot-spots의 구현이 정교해지고 있다. ${ }^{15),}{ }^{47)}$

\section{(3) 3 세대 SERS hot-spots}

3세대 Hot-spots은 플라즈모닉 나노입자가 기판 위에 존재할 때 조사된 빛에 의해 나노입자로부터 발생하는 Hot-spots과 기판 물질의 계면에서 발생하는 Hot-

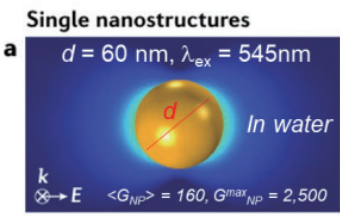

Coupled nanostructures

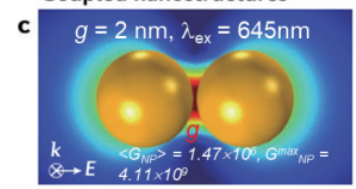

Nanoparticle aggregate and oligomer
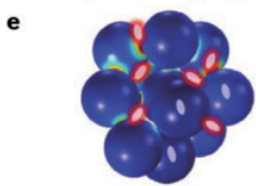
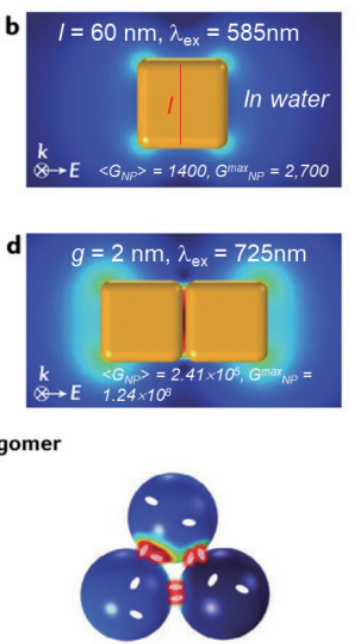

\section{Nanoparticle ordered assembly}

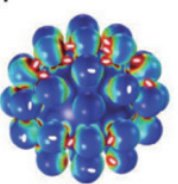

Structured surface

\section{$\mathbf{g}$}

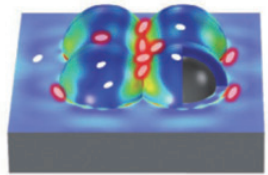

Nanoheptamer and nanocone

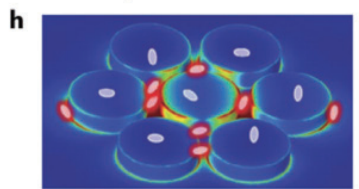

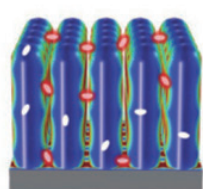
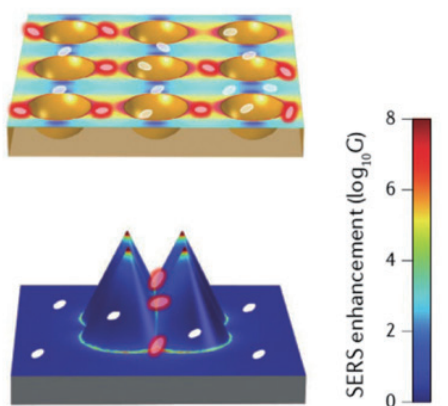

그림 6. 미량 분자 검출을 위한 1세대 및 2세대 SERS hot-spots. ( $\mathrm{a}$ d) 물에 분산된 단일 구형 금 나노입자 (a), 금 나노큐브(b), 구형 금 나 노 이량체(c), 및 금 나노큐브 이량체(d)의 Finite-element simulations(FES) 결과. (e h) 2세대 SERS hot-spots 구현을 위한 나노 구조체 결합에 대한 모식도. $\left\langle G_{N P}\right\rangle$ : 나노 구조체 전체 표면의 평균 SERS 증폭 지수, $G^{\max }{ }_{N P}$ : 나노 구조체 표면에서 최고 SERS 증폭 지수, $k$ : 입사된 빛의 wave-vector, $E$ : 전기장, $l_{e x}:$ 여기 레이저 파장 (출처 : 참고문헌 15,47 ) 
spots이 합쳐지면서 발생한다(그림 7). ${ }^{15), 38)} \mathrm{Gold}$ 이량체 가 $\mathrm{Si}$-기판 위에 놓여있을 때 이량체 사이 갭 뿐만 아니 라 기판과 이량체 사이에서도 SERS hot-spots이 발생 하면서 단일 Gold 나노입자와 비교하여 $\left\langle G_{S u b}\right\rangle$ 가 약 $10^{3}$
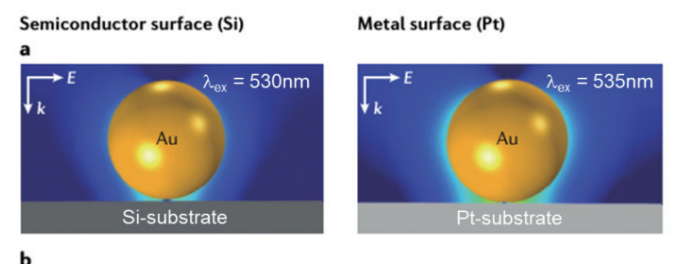

b
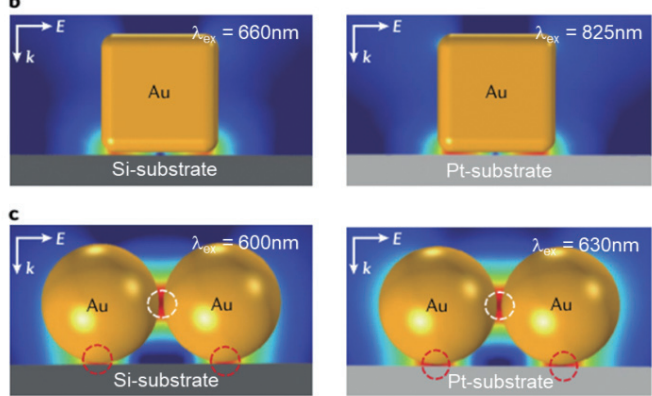

d
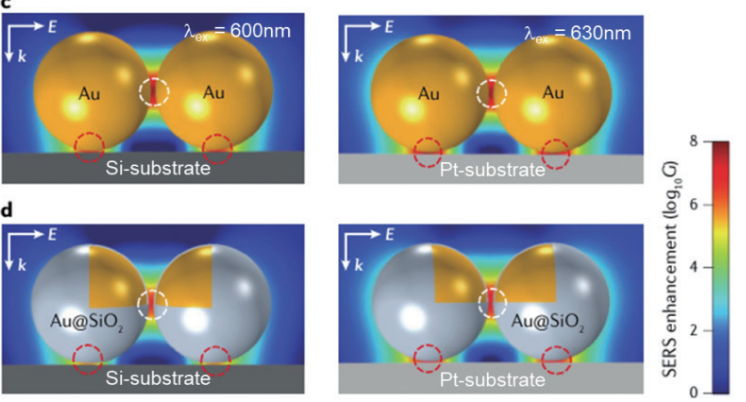

그림 7. Silicon 및 Pt 기판(분석 대상 물질) 위에 올려진 플라즈모닉 나 노입자들의 SERS 증가 분포에 대한 Finite-element simulation(FES) 결과. (a) Si 기판 위에 존재하는 단일 Gold 나노입자에 $\lambda_{e x}=530$ $\mathrm{nm}$ 를 갖는 여기 광원에 의한 FES 결과 $\left\langle\left\langle G_{\text {Sub }}\right\rangle=94, G^{\text {max }}{ }_{\text {Sub }}=2.03\right.$ $\left.\times 10^{3}\right)$ 및 $\mathrm{Pt}$ 기판 위에 존재하는 단일 Gold 나노입자에 $\lambda_{\mathrm{ex}}=535$ $\mathrm{nm}$ 를 갖는 여기 광원에 의한 FES 결과 $\left\langle\left\langle G_{\text {sub }}\right\rangle=1.30 \times 10^{3}, G^{\text {max }}{ }_{\text {sub }}\right.$ $\left.=4.32 \times 10^{4}\right),(\mathrm{b}) \mathrm{Si}$ 기판 위에 존재하는 단일 Gold 나노큐브에 $\lambda_{\mathrm{ex}}$ $=660 \mathrm{~nm}$ 를 갖는 여기 광원에 의한 FES 결과 $\left\langle\left\langle G_{\text {Sub }}\right\rangle=1.48 \times 10^{6}\right.$, $\left.G^{\text {max }}{ }_{\text {sub }}=1.42 \times 10^{7}\right)$ 및 $\mathrm{Pt}$ 기판 위에 존재하는 단일 Gold 나노큐브 에 $\lambda_{\mathrm{ex}}=825 \mathrm{~nm}$ 를 갖는 여기 광원에 의한 $\mathrm{FES}$ 결과 $\left\langle\left\langle G_{\mathrm{Sub}}\right\rangle=7.31\right.$ $\times 10^{5}, G^{\text {max }}$ Sub $\left.=5.15 \times 10^{6}\right)$, (c) Si 기판 위에 존재하는 Gold 나노 이 량체에 $\lambda_{\mathrm{ex}}=600 \mathrm{~nm}$ 를 갖는 여기 광원에 의한 FES 결과 $\left\langle G_{\text {Sub }}\right\rangle=$ $1.04 \times 10^{5}, G^{\text {max }}$ Sub $\left.=6.85 \times 10^{6}, G^{\text {max }}{ }_{N P}=6.76 \times 10^{7}\right)$ 및 $\mathrm{Pt}$ 기판 위 에 존재하는 Gold 나노큐브 이량체에 $\lambda_{\mathrm{ex}}=630 \mathrm{~nm}$ 를 갖는 여기 광 원에 의한 FES 결과 $\left\langle G_{S u b}\right\rangle=1.02 \times 10^{6}, G^{\text {max }}{ }_{S u b}=9.01 \times 10^{7}, G^{\text {max }}{ }_{N P}$ $\left.=7.19 \times 10^{7}\right)$, (d) Si 기판 위에 존재하는 $\mathrm{Au} @ \mathrm{SiO}_{2}$ core@shell 이 량체에 $\lambda_{\mathrm{ex}}=580 \mathrm{~nm}$ 를 갖는 여기 광원에 의한 $\mathrm{FES}$ 결과 $\left\langle\left\langle G_{\mathrm{Sub}}\right\rangle=\right.$ $\left.1.74 \times 10^{4}, G^{\text {max }}{ }_{\text {Sub }}=8.37 \times 10^{5}, G^{\max }{ }_{N P}=6.56 \times 10^{6}\right)$ 및 $\mathrm{Pt}$ 기판 위 에 존재하는 $\mathrm{Au} @ \mathrm{SiO}_{2}$ core@shell 이량체에 $\lambda_{\mathrm{ex}}=600 \mathrm{~nm}$ 를 갖는 여기 광원에 의한 FES 결과 $\left\langle\left\langle G_{\text {Sub }}\right\rangle=2.07 \times 10^{5}, G^{\text {nax }}\right.$ Sub $=1.16 \times 10^{7}$, $\left.G^{\text {max }}{ }_{N P}=1.39 \times 10^{7}\right)$. Gold 나노입자의 지름은 $60 \mathrm{~nm}$ 이며 $\mathrm{Au} @ \mathrm{SiO}_{2}$ 에서 Silica의 두께는 $2 \mathrm{~nm}$ 이다. 이량체 사이의 간격은 $2 \mathrm{~nm}$ 이며 기 판과 나노입자 사이의 거리는 $1 \mathrm{~nm}$ 이다. $\left\langle G_{\text {Sub }}\right\rangle$ : 기판에서 발생한 평 균 SERS 증폭 지수, $G^{\text {max }}$ Sub : 기판에서 최고 SERS 증폭 지수. (출처 : 참고문헌 15,38$)$
배 증가한 것을 확인할 수 있다. 이와 같이 기판과 플라즈 모닉 나노구조체 사이에서 생성된 Hot-spots은 기판 표 면에 존재하는 물질을 분석하고자 할 때 매우 강력한 인 자가 될 수 있다. 이때 유전체로 구성된 기판의 굴절률 값 이 증가할수록 $\left\langle G_{S u b}\right\rangle$ 가 증가한다. $\mathrm{Pt}-$ 기판의 경우는 $\mathrm{Si}-$ 기판 보다 $\left\langle G_{\text {Sub }}\right\rangle$ 가 약간 더 증가한 것을 볼 수 있는 데 이는 Gold-이량체와 $\mathrm{Pt}-$ 기판 사이의 추가적인 플라 즈몬 결합이 발생하기 때문이다. $\mathrm{Au} @ \mathrm{SiO}_{2}$ core@shell 이량체가 $\mathrm{Si}$ - 또는 $\mathrm{Pt}$-기판 위에 놓여있을 때도 이량체 사이의 Gap과 기판과 이량체 사이에서 SERS hotspots이 발생한다. SERS 효과가 없는 $\mathrm{SiO}_{2}$ shell에 의하 여 $\left\langle G_{\text {Sub }}\right\rangle$ 가 다소 감소하지만 계면에서 발생할 수 있는 원하지 않는 간섭 신호를 피할 수 있다는 장점이 있다. 3 세대 Hot-spots은 실리콘, 세라믹과 같이 널리 사용하 는 물질의 표면을 분석하고자 할 때 활용될 수 있다. ${ }^{15)}$

\section{(4) Tip-enhanced Raman spectroscopy(TERS)}

2000년대 초반에 발명된 TERS는 Scanning probe microscopy 팁(Tip)에 $\mathrm{Au}, \mathrm{Ag}$ 와 같은 플라즈모닉 금속 을 코팅하여 팁이 시료 표면에 접근할 때 단일 Hot-spot 을 생성시킴으로써 약 $10 \mathrm{~nm}$ 의 공간 분해능에서 재료 표 a

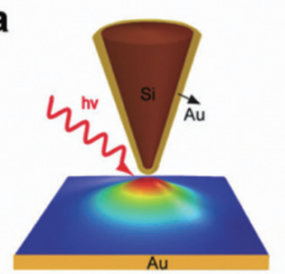

C

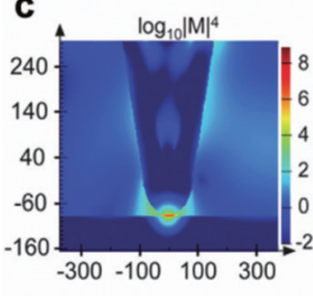

b

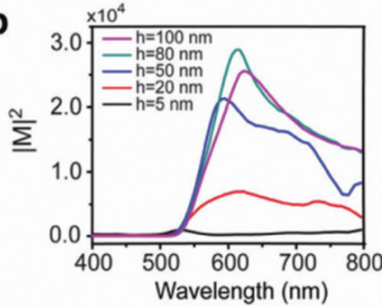

d

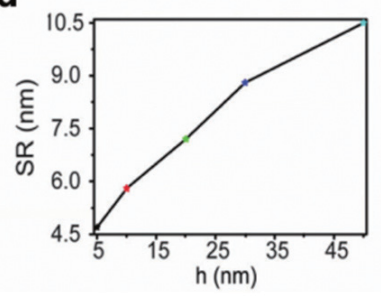

그림 8. (a) Gold 기판 위에 Si@Au AFM tip에 의한 전기장 증폭에 대 한 계산 모델, (b) Au 두께(h)에 따른 전기장 증폭 변화, (c) $\lambda_{\mathrm{ex}}=615 \mathrm{~nm}$ 에서 여기된 Gold 기판 위에 Si@Au AFM tip의 근접장(Near-field) 분포, (d) Au 두께(h)에 따른 공간 분해능 (Spatial resolution). (출처 : 참고문헌 52) 


\section{특 집 ㅁㅁ 장의순}

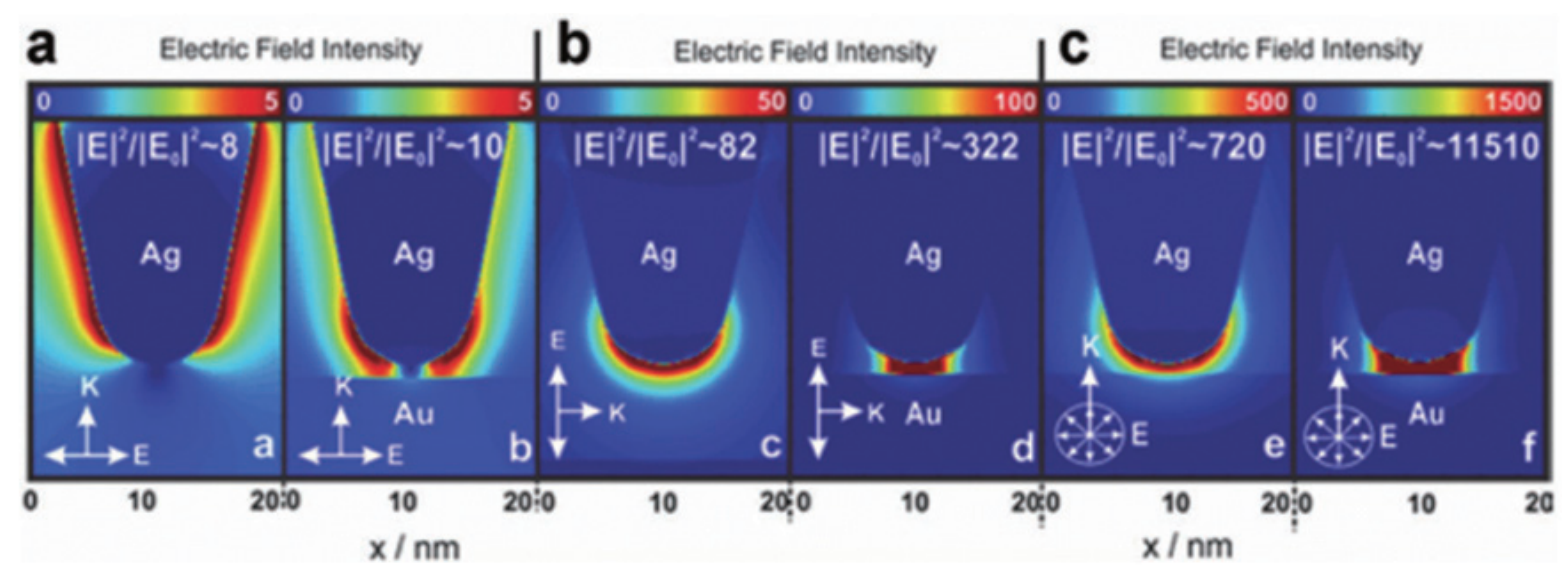

그림 9. (a) 기판에 평행한 편광, (b) 기판에 수직인 편광, 및 (c) 방사성 편광에 의해 여기된 TERS tip 부근에서의 전기장 분포. (출처 : 참고문헌 53)

면의 구조뿐만 아니라 화학적 조성을 동시에 밝혀낼 수 있는 분석 방법이다. ${ }^{48-51)}$ 일반적으로 플라즈모닉 금속 코 팅 층의 두께를 조절함으로써 SERS 효과를 최적화 시킬 수 있다. 그림 8은 $\mathrm{Si}-\mathrm{AFM}$ tip의 표면에 코팅된 $\mathrm{Au}$ 의 두께(h)에 따라 SERS 신호가 변화되는 것을 보여 주고 있다. ${ }^{52)}$

또한 TERS에서 SERS 신호의 세기는 그림 9와 같이 여기 광의 조사 방향에 따라 달라진다. ${ }^{53)}$

\section{(5) Shell-isolated nanoparticle-enhanced Raman spectroscopy(SHINERS)}

TERS를 이용한 물질의 구조 및 화학적 분석은 획기적
인 분석방법을 제시하였음에도 불구하고 직경 $20 \sim 50$ $\mathrm{nm}$ 의 팁 부분에 국한되어 발생하는 SERS 신호는 다소 약하기 때문에 TERS 연구는 라만 단면적이 큰 분자로 제 한되어 왔다. 또한, 일반적인 응집된 플라즈모닉 나노구 조체의 3세대 Hot-spots을 이용한 분석 방법은 SERS 신호는 매우 강하다는 장점이 있으나 나노구조체와 분석 물질이 직접적으로 접촉되기 때문에 나노구조체와 분석 물질의 화학적 결합에 의한 노이즈 발생과 광반응이 발생 할 수 있다는 단점이 발생한다. 2010년 Z. Q. Tian 그룹 에 의해 고안된 SHINERS 방법은 매우 얇은 두께의 Silica 또는 Alumina등을 플라즈모닉 나노구조체에 코 팅함으로써 분석물질과의 화학적 결합을 피할 수 있으며
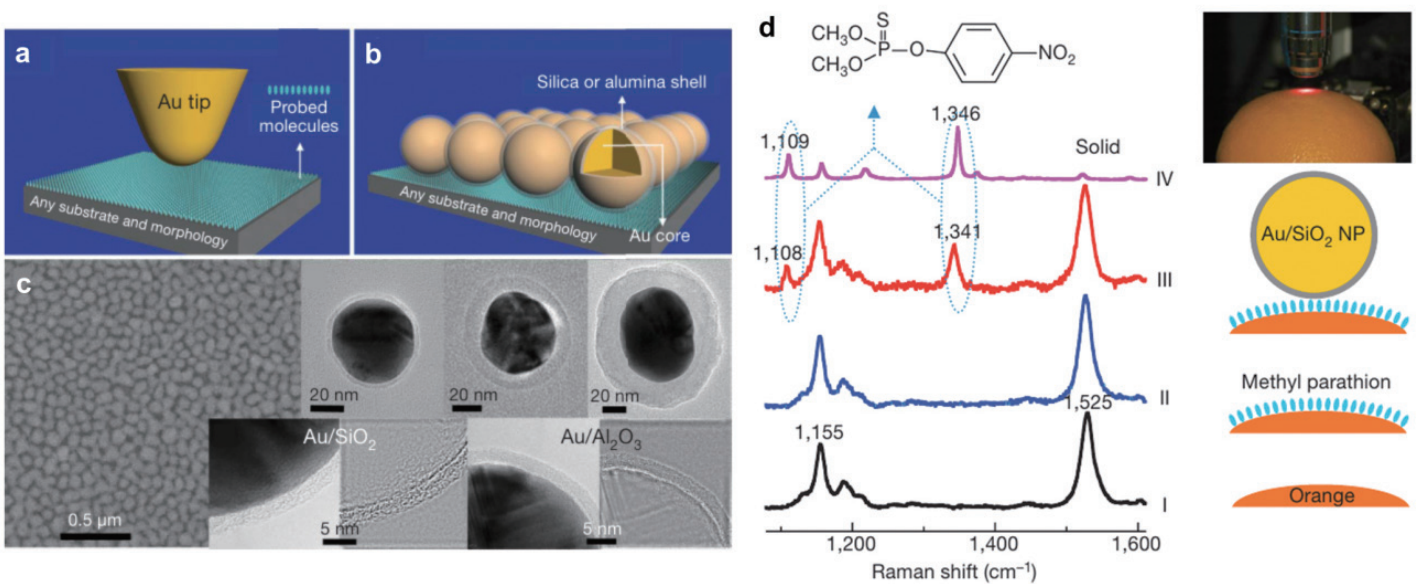

그림 10. (a) TERS 방법, (b) SHINERS 방법, (c) Au@SiO, Au@ $@ \mathrm{Al}_{2} \mathrm{O}_{3}$ core@shell 나노입자의 SEM 및 TEM 사진, (d) 메틸파라티온으로 오염 된 오렌지의 라만 및 SHINERS 분석결과(레이저 파워 : $0.5 \mathrm{~mW}$ ). (출처 : 참고문헌 54 ) 
이러한 Core@shell 나노구조체를 어셈블리화하여 3세 대 Hot-spots을 생성시킴으로써 단일 팁을 사용하는 $\mathrm{TERS}$ 와 비교하여 분석하고자 하는 물질의 월등한 SERS 신호를 얻을 수 있다는 장점이 있다. ${ }^{54)}$ 그림 10은 $\mathrm{Au@}$ $\mathrm{SiO}_{2}$ 또는 $\mathrm{Au} @ \mathrm{Al}_{2} \mathrm{O}_{3}$ 나노입자를 이용하여 살충제인 메 틸파라티온(Methyl parathion)에 의해 오염된 오렌지 표면을 일반적인 라만과 SHINERS 방법으로 검출한 결 과를 보여주고 있다. 일반 라만으로는 검출되지 않는 메 틸파라티온의 라만신호가 SHINERS로는 검출되는 것을 확인할 수 있다. ${ }^{54)}$

SHINERS 방법은 분석물질과의 화학반응을 최소화 할 수 있다는 장점 때문에 일반적인 라만 분광법으로 측정하 기 어려운 다양한 전이금속의 단결정 표면에서 전기촉매 반응 및 화학적 흡착의 특성을 실시간으로 분석하기 위해 서 많이 활용되고 있다. ${ }^{47), 54-61)}$

\subsection{SERS를 이용한 바이오 물질 분석}

\section{(1) Raman reporter-labeled SERS 분석 및 Label-free SERS 분석}

SERS를 이용한 바이오 물질 분석 방법은 크게 Raman reporter-labeled SERS 분석법과 Label-free SERS 분석법이 있다. Raman reporter-labeled SERS 방법은 라만 활성분자와 항체를 플라즈모닉 나노구조체 표면에 고정시킨 후 바이오 물질과 섞어주면 항원을 갖는 바이오 물질과 항원-항체 반응을 통해 결합하면서 라만 활성분 자의 SERS 신호를 통해 타겟 바이오 물질의 존재 유무를 확인할 수 있는 방법이다. 일반적으로 라만 단면적이 큰 분자들을 라만 활성분자로 활용하기 때문에 SERS 신호 가 강해 효과적으로 빠른 시간 안에 타깃 바이오물질의 유무를 확인할 수 있다는 장점이 있으나 직접적인 바이오 물질의 SERS 신호가 아니기 때문에 라만 활성분자에 의 한 간접적인 SERS 분석 방법이라고 할 수 있다. Labelfree SERS 분석 방법은 플라즈모닉 나노구조체 표면에 결합된 바이오 물질의 SERS 신호를 측정하는 방법으로 써 타깃 바이오물질의 화학적 분자 구조를 직접적으로 분 석할 수 있다는 장점이 있다. 그러나 앞서 언급한 바와 같

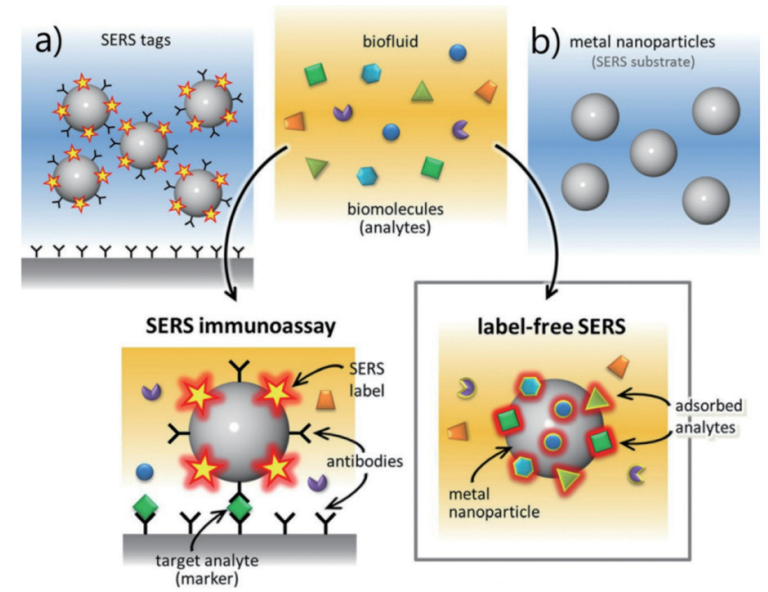

그림 11. (a) Raman reporter-labeled SERS 분석, 및 (b) Label-free $\mathrm{SERS}$ 분석 방법에 의한 바이오 물질 검출에 대한 모식도. ( 출처 : 참고문헌 62)

이 SERS 신호는 분석물질과 플라즈모닉 나노구조체 표 면 사이의 거리가 약 $2 \mathrm{~nm}$ 이상으로 증가하게 되면 급격 히 SERS 신호가 감쇠하기 때문에 나노구조체 표면에 분 자량이 큰 항체를 매개로 하여 타깃 바이오물질과 결합시 키지 못하고 분자량이 짧은 결합 매개체를 이용하거나 비 특이적 흡착 또는 결합된 바이오물질을 분석할 수 밖에 없다는 단점이 있다.

Raman reporter-labeled SERS 분석에서 Reporter 분 자의 선택은 매우 중요하며 주요 요구사항은 다음과 같다.

(1) SERS 신호를 크게 증폭하기 위해서는 라만 산란 단 면적이 커야 한다. 추가적으로 플라즈모닉 나노구 조체의 LSPR 유도를 위한 여기 광(Excitation light)의 파장과 일치하는 흡수 파장을 갖는다면 공 명을 통해 SERS 신호가 추가적으로 $10^{2} \sim 10^{3}$ 배 증 가할 수 있다. ${ }^{63)}$

(2) 검출 환경에 존재하는 다른 바이오 물질들에 의하여 타깃 물질이 치환되거나 떨어지지 않도록 나노구조 체 표면과 강한 결합력을 갖아야 한다. 이를 위해서 는 물리적인 흡착보다는 화학적 결합이 유리하다. 64) 그러나 Hot-spot에서 거리에 따른 SERS 신호 감쇠 효과를 감안하여 비교적 분자량이 작은 결합 매개체를 이용해야 한다.

(3) 분석하고자 하는 생체 분자들의 라만 지문 영역과 
중첩되지 않는 Reporter를 선택해야 한다. 생체 분 자들의 라만 신호가 없는 사일런트 영역(silent region)으로 알려진 $2000 \sim 2700 \mathrm{~cm}^{-1}$ 이며 이 영 역에서 특징적인 신호를 나타내는 Alkyne, Azide, Nitrile, Deuterium, 및 Metal-carbonyl을 포함 한 여러 종류의 Reporter들이 알려져 있다. ${ }^{63), 65-67)}$

\section{(2) 단백질 분석 : Label-free SERS}

단백질은 질병의 대표적인 진단 물질로 활용되고 있기 때문에 단백질 분석법은 매우 중요하게 인식되고 있다. 표 3 은 단백질과 지질의 라만 스펙트럼에서 일반적으로 관찰되는 진동 주파수를 보여주고 있다. Pyrrole과 Aromatic 분자들의 라만 단면적이 크기 때문에 단백질 중 이들을 많이 포함하고 있는 발색단(chromophore) 분 자를 포함하고 있는 Cytochrome c, Hemoglobin, Myoglobin, Green fluorescent protein 등이 SERS 분 석에 많이 활용된다. ${ }^{68-71)}$

그러나 발색단을 포함하지 않는 단백질들은 SERS 신 호가 약하다는 단점이 있으며 또한 플라즈모닉 나노구조

표 3. 지질과 단백질의 라만 진동모드 (출처 : 참고문헌 72-74)
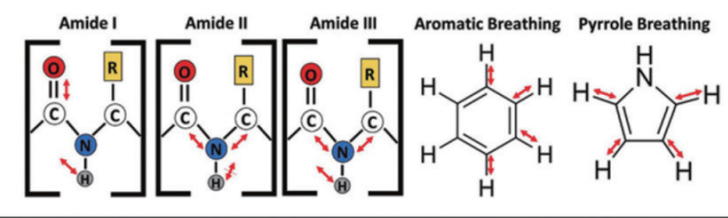

\begin{tabular}{|c|c|c|c|}
\hline $\begin{array}{l}\text { Vibrational } \\
\text { mode }\end{array}$ & $\begin{array}{l}\text { Frequency } \\
\left(\mathrm{cm}^{-1}\right)\end{array}$ & $\begin{array}{l}\text { Vibrational } \\
\text { mode }\end{array}$ & $\begin{array}{l}\text { Frequency } \\
\left(\mathrm{cm}^{-1}\right)\end{array}$ \\
\hline Lipid $=\mathrm{CH}$ & 3007 & Lipid V C-C & 1125 \\
\hline Lipid Vas $=\mathrm{CH}_{3}$ & 2959 & Lipid V C-C & 1089 \\
\hline Lipid Vs $=\mathrm{CH}_{3}$ & 2925 & Lipid V P-O & 1096 \\
\hline Lipid Vas $=\mathrm{CH}_{2}$ & 2882 & Protein Phe & 1030 \\
\hline Lipid Vs $=\mathrm{CH}_{2}$ & 2847 & Protein Phe & 1004 \\
\hline Lipid V C $=0$ & 1737 & Protein Trp Val & 960 \\
\hline Protein amide I & 1670 & Protein $\mathrm{N}-\mathrm{C} \alpha-\mathrm{C}$ & 940 \\
\hline Lipid V C $=\mathrm{C}$ & 1657 & Protein Trp & 880 \\
\hline Protein Try, Trp, Phe & 1620 & $\begin{array}{l}\text { Lipid Vasy } \\
\mathrm{N}^{+}\left(\mathrm{CH}_{3}\right)_{3}\end{array}$ & 875 \\
\hline Protein indole ring & 1550 & Protein Tyr & 855 \\
\hline Protein $\mathrm{C}-\mathrm{H}$ (def.) & 1450 & Protein Tyr & 830 \\
\hline Lipid scissor $\mathrm{CH}_{2} / \mathrm{CH}_{3}$ & 1442 & Protein Trp & 760 \\
\hline Protein Trp $\mathrm{C} \alpha-\mathrm{H}$ & 1340 & $\begin{array}{l}\text { Lipid } \\
\text { ethanolamine }\end{array}$ & 760 \\
\hline Lipid twist $\mathrm{CH}_{2}$ & 1300 & Lipid Vs N ${ }^{+}\left(\mathrm{CH}_{3}\right)_{3}$ & 719 \\
\hline Protein amide III & $1230-1280$ & Protein Tyr & 647 \\
\hline $\begin{array}{l}\text { Lipid deformation } \\
=\mathrm{CH}\end{array}$ & 1267 & Protein S-S & $500-550$ \\
\hline Protein $\mathrm{C}-\mathrm{N}$ & 1130 & & \\
\hline
\end{tabular}
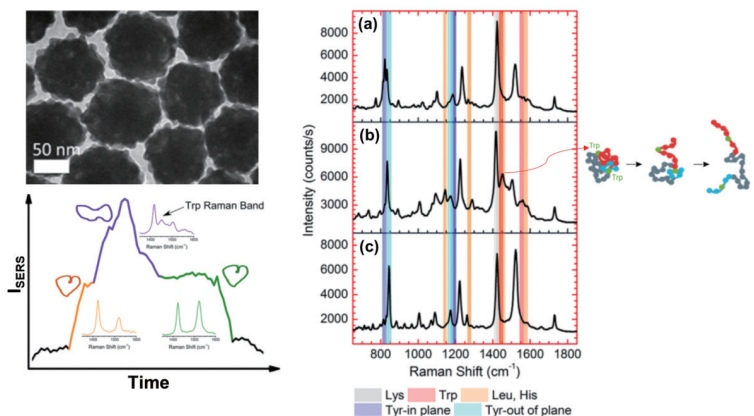

그림 12. Gold 나노어셈블리의 TEM 사진 및 이를 이용한 시간 에 따른 BSA 단백질의 SERS 스펙트럼. (a) 890 895 초, (b) $900 \sim 910$ 초, (c) $910 \sim 935$ 초, Lysine(gray), Tryptophan(red), Leucine/histidine(orange), Tyrosine in plane(blue), Tyrosine out of plane(cyan). (출처 : 참고문 헌 75,76$)$ 


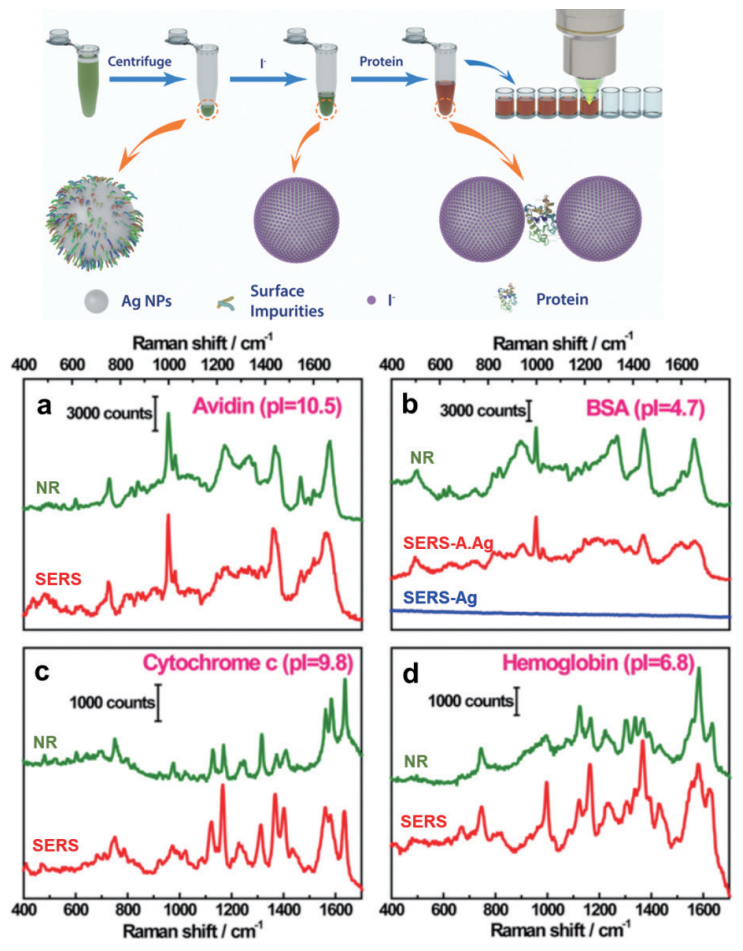

그림 13. Gold 나노어셈블리의 TEM 사진 및 이를 이용한 시간 에 따른 BSA 단백질의 SERS 스펙트럼. (a) $890 \sim 895$ 초, (b) $900 \sim 910$ 초, (c) $910 \sim 935$ 초, Lysine(gray), Tryptophan(red), Leucine/histidine(orange), Tyrosine in plane(blue), Tyrosine out of plane(cyan). (출처 : 참고문 헌 77-79)

나노입자 사이의 강한 결합을 방해함으로써 단백질 구조 가 유지된 것이 아닌가 추측하였다. 그러나 강한 SERS 신호를 위해서는 단백질과 플라즈모닉 나노구조체 사이 의 거리가 충분히 가까워야 하며 이는 두 물질의 강한 결 합을 통해 만족될 수 있다. 만일, Iodine에 의해 두 물질 의 결합이 약화된다면 단백질 분자가 쉽게 플라즈모닉 나 노구조체로부터 분리될 수 있으며 이는 SERS 신호를 약 하게 만드는 원인이 될 것으로 판단된다.

\section{(3) DNA 분석 : Label-free SERS}

단백질과 함께 질병을 진단하는데 가장 많이 활용되는 바이오물질이 DNA이다. DNA SERS 스펙트럼에서는 다 음과 같이 4 개의 주요한 영역이 존재한다. $\left.{ }^{80), ~}{ }^{81}\right)$

(1) $500 \sim 820 \mathrm{~cm}^{-1}$ : Purine(adenine, A; thymine, T)과 Pyrimidine(cytosine, C; guanine, G) 잔기
들에 의한 Ring stretching bands

(2) $820 \sim 1150 \mathrm{~cm}^{-1}$ : Phosphodioxy 부분 $\left(\mathrm{PO}_{2}^{-}\right)$에 의한 Symmetric stretching mode $\left(1089 \mathrm{~cm}^{-1}\right)$ 를 포함한 Deoxyribose-linked phosphodiester network에 의한 bands
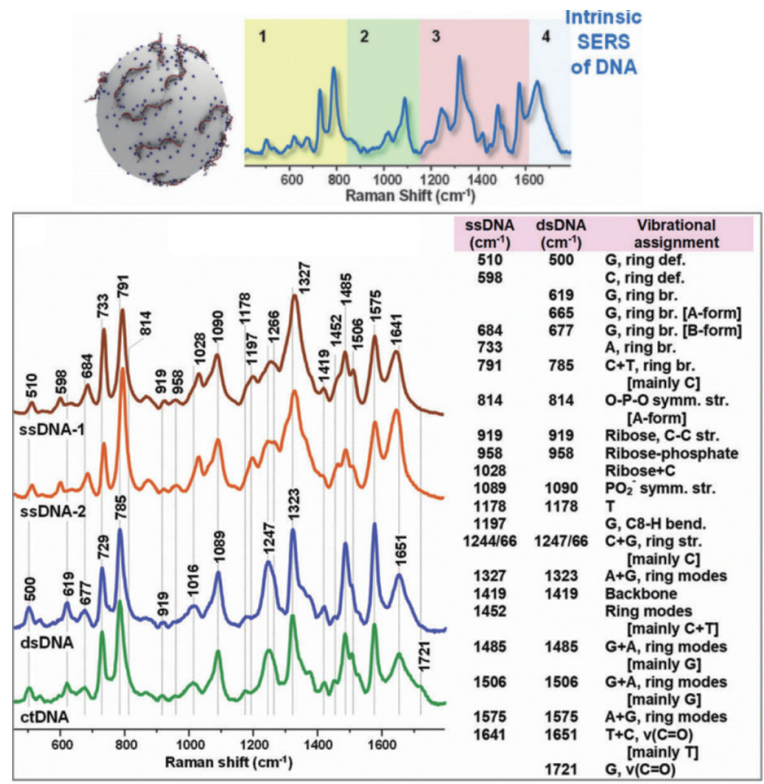

그림 14. Label-free DNA SERS 스펙트럼에서 나타나는 4개의 특징 적인 Bands에 대한 모식도, 2개의 상보적인 21-nt singlestrain(ss) DNA(ssDNA-1 : CATCGCAGGTACCTGTAAGAG, ssDNA-2 : GTAGCGTCCATGGACATTCTC), 해당 double-strain(ds) DNA, 및 송아지 흉선(thymus of calves) DNA에 대한 SERS 스펙트럼과 각 진동모드에 대한 정보. (출처 : 참고문헌 80,81 )

(3) $1150 \sim 1620 \mathrm{~cm}^{-1}$ : 핵염기(Nucleobases)의 inplane ring vibrations에 의해 영향을 받을 수 있는 겹치는 복잡한 bands

(4) $1620 \sim 1720 \mathrm{~cm}^{-1}$ : Carbonyl stretching modes 의 중첩으로 인한 넓은 bands

각 영역에 대한 자세한 진동 모드는 그림 14에 나타내 었다.

플라즈모닉 나노구조체를 이용한 DNA SERS 분석 접 근법은 그림 15 와 같이 크게 2 가지가 있다. ${ }^{81)}$

첫번째는 플라즈모닉 나노구조체의 표면에 존재하는 이온 또는 분자들을 대체하여 DNA의 핵염기가 결합되는 
(a) DIRECT NUCLEOBASE/METAL INTERACTION

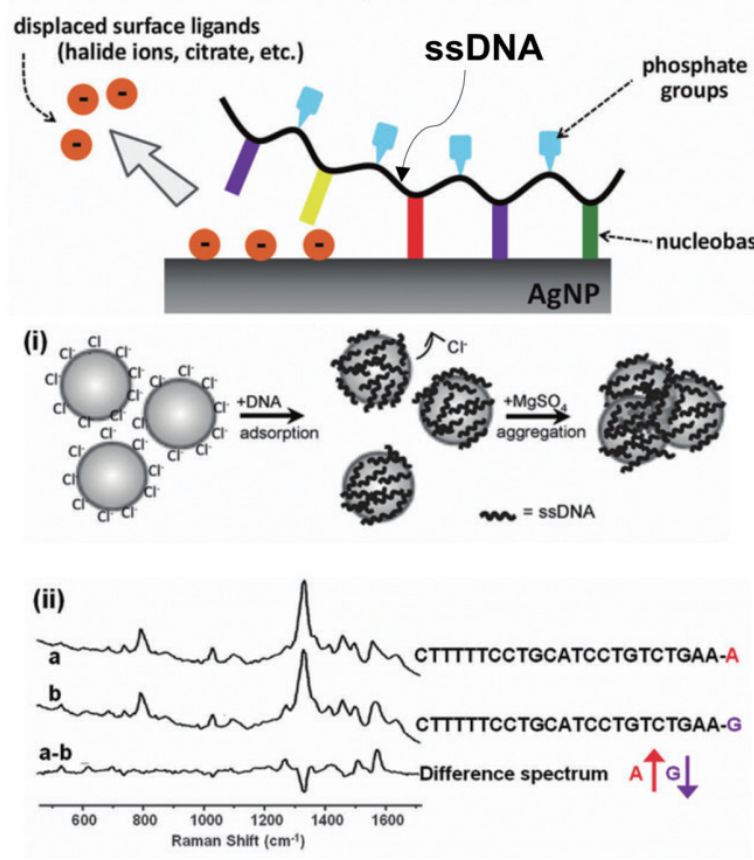

(b) ELECTROSTATIC ADHESION MEDIATED BY BACKBONE NEUTRALIZERS
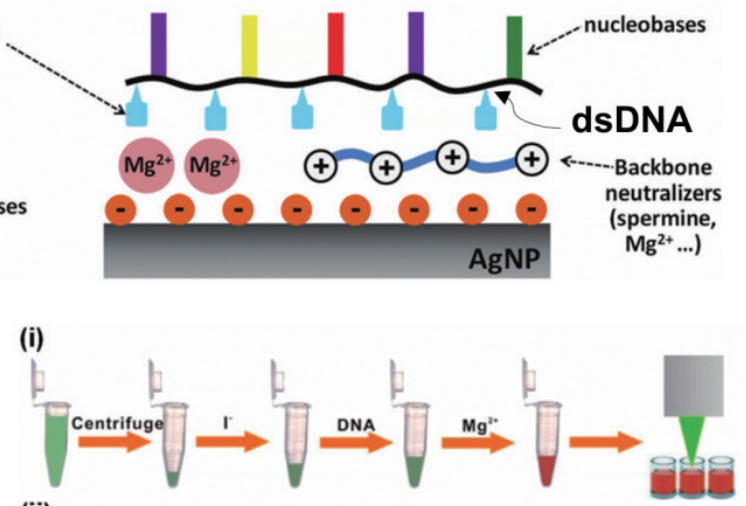

(ii) $\mathrm{A}$

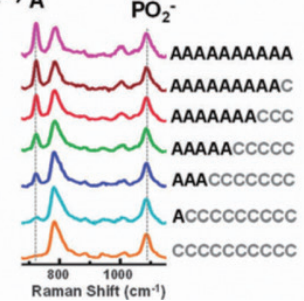

(iii)

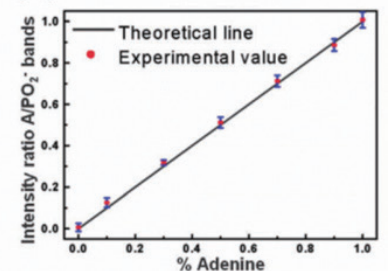

그림 15. (a) 핵염기-금속표면 직접 결합 및 (b) Phosphate backbone-금속표면 정전기적인 결합 방법을 이용한 DNA SERS 분석에 대한 모 식도 및 스펙트럼. (출처 : 참고문헌 $77,81,82$ )

형태로 핵염기의 SERS 신호가 강하게 나타나는 특징이 있다. 이와 같이 DNA를 분석하기 위해서는 먼저 dsDNA 를 열처리 방법 등을 통하여 $\mathrm{ssDNA}$ 로 만들어야 한다는 단점이 있다. ${ }^{81)}$ 이에 비하여 두번째 방법은 DNA와 플라 즈모닉 나노구조체의 정전기적인 결합(Electrostatic binding)을 이용한다. 예를 들면, Halide 이온이 코팅된
금속 나노입자 표면에 Polyamine 또는 $\mathrm{Mg}^{2+}$ 이온을 도 입시켜 표면 전하를 양으로 만들면 음전하를 띄는 DNA 의 Phosphate backbone이 정전기적 힘으로 결합될 수 있다. 이때, Halide-metal bond의 세기가 증가 $(\mathrm{Cl}-<$ $\mathrm{Br}-<\mathrm{I}-)$ 할수록 음전하를 띄는 Phosphate backbone 이 나노입자 표면에 직접적으로 결합할 확률을 줄여주고 (a)

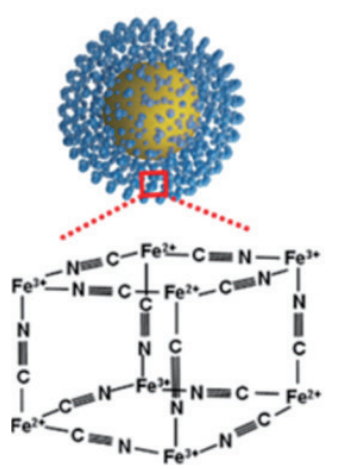

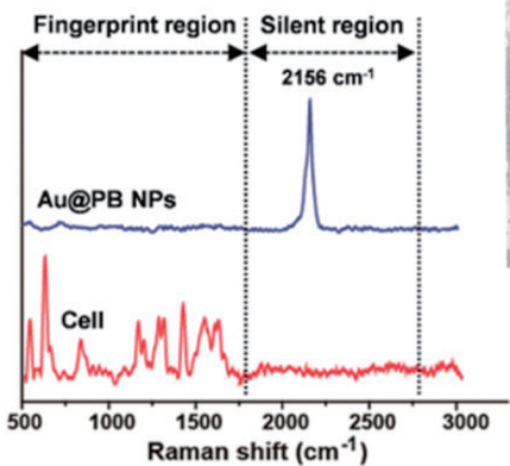

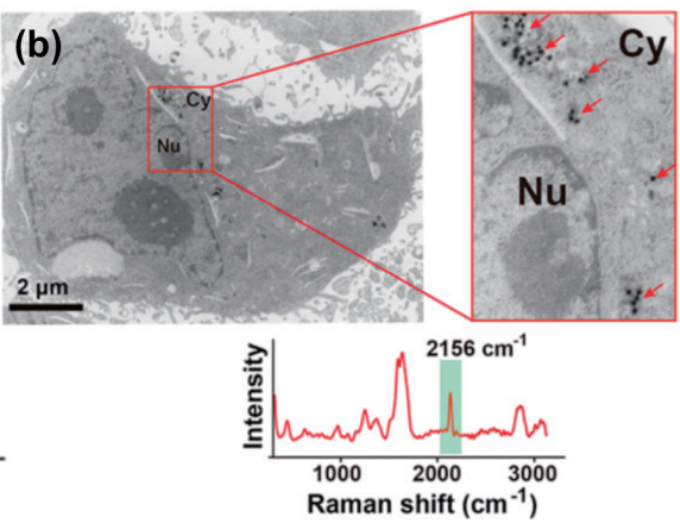

그림 16. (a) Au@PB 나노입자에 대한 모식도 및 세포와 Au@PB 나노입자의 라만 스펙트럼 비교, (b) 암세포(HeLa)에 들어간 Au@PB 나노입 자의 TEM 사진 및 SERS 스펙트럼. (출처 : 참고문헌 30, 83) 


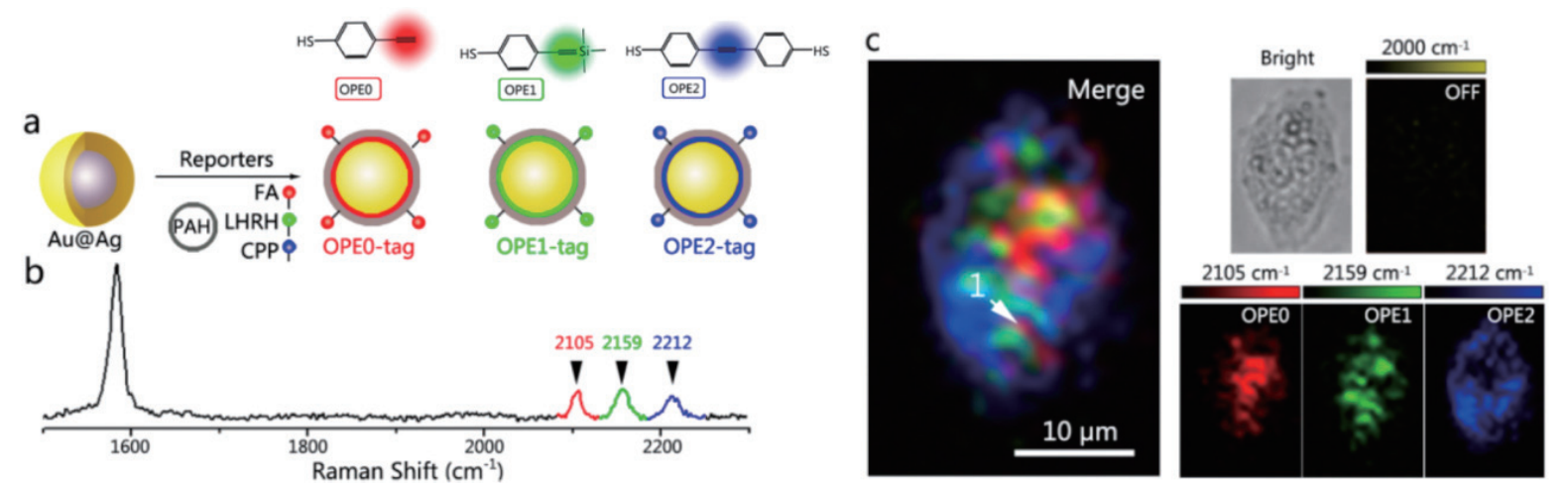

그림 17. (a) 3가지 4-ethynylbenzenethiol(OPE) 유도체들을 이용한 SERS 나노구조체의 모식도, (b) OPEO OPE2 분자들의 일반 라만 스 펙트럼, 및 (c)이를 이용한 다중 SERS 암세포(HeLa) 영상; Folate(FA), Luteinizing hormone-releasing hormone(LHRH), CALNNR polypeptide(CPP). (출처 : 참고문헌 84)

양이온과의 정전기적 결합률을 높여준다. 첫번째 방법과 달리 Phosphate backbone이 결합하기 때문에 dsDNA 의 측정이 가능하며 Phosphodioxy symmetric stretching mode가 증가하는 특징이 있다.

\section{(4) 세포 분석 : Raman reporter-labeled SERS 및 Label-free}

\section{SERS}

앞서 언급한 바와 같이 Raman reporter-labeled SERS 분석방법에서 중요한 것은 Reporter의 선정이며 특히 세포 안에는 다양한 생체분자들이 존재하기 때문에 사일런트 영역 $\left(2000 \sim 2700 \mathrm{~cm}^{-1}\right)$ 에서 강한 라만 지문
신호를 나타내는 Reporter를 선택하는 것이 중요하다. 예를 들면, D. Liu 그룹은 Prussian blue(PB)를 Reporter로 하여 Gold 나노입자에 결합시킨 후 암세포 (HeLa cell) 내에서 SERS를 측정한 결과 $2156 \mathrm{~cm}^{-1}$ 에서 $\mathrm{PB}$ 의 강한 라만 신호가 검출됨을 확인 하였다. ${ }^{83)}$

한편, J. - M. Hu 그룹은 알킨기(Alkyne group)의 사 일런트 영역에서 라만 진동 주파수 영역이 서로 다른 3 개 의 4-ethynylbenzenethiol(OPE) 유도체들을 Au@Ag core@shell 나노구조체의 $\mathrm{Au}-\mathrm{Ag}$ 간 계면에 결합시켜 SERS 물질을 합성한 후 수용체들을 이용하여 암세포 (HeLa cell)의 다른 위치에 고정된 나노복합체로부터 라

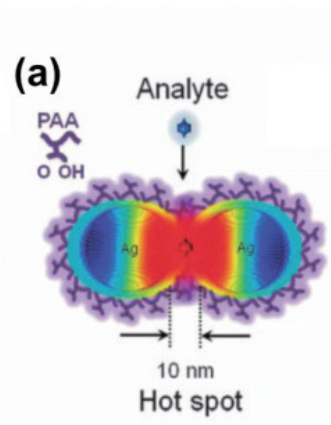

(c)

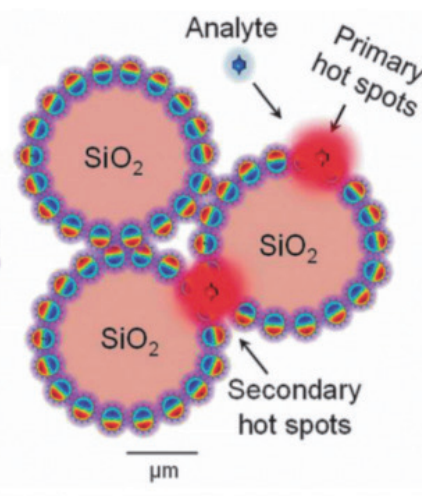

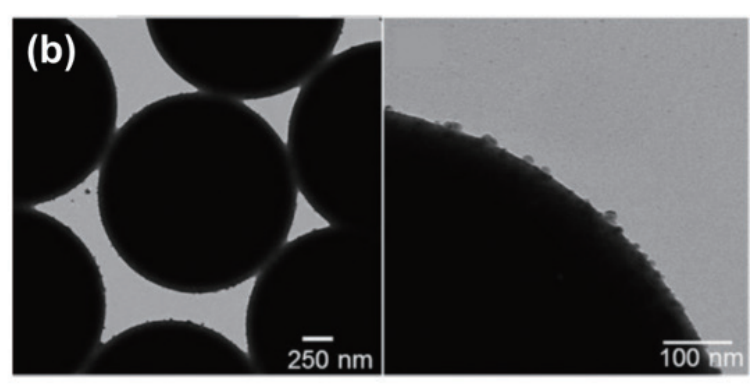

(d)

그림 18. (a) Ag-PAA로 코팅된 마이크로 Silica bead(SiO_@Ag) 클러스터로부터 발생하는 1차 및 2차 SERS hot-spots에 대한 모식도, (b) $\mathrm{SiO}_{2} @ \mathrm{Ag}$ 의 TEM 사진, (c) $\mathrm{SiO}_{2} @ \mathrm{Ag}$ 클러스터 형성에 따른 SERS 스펙트럼 변화, (d) $\mathrm{SiO}_{2} @ \mathrm{Ag}$ 클러스터를 이용한 NIH/3T3 섬유아 세포의 라만 현미경 사진(숫자는 $\mathrm{SiO}_{2} @ \mathrm{Ag}$ 클러스터에 의해 발생한 SERS 신호) 및 핵, 핵막, 세포질에서 검출된 SERS 스펙트럼. ( 출처 : 참고문헌 85) 


\section{특 집 ㅁㅁ장의순}
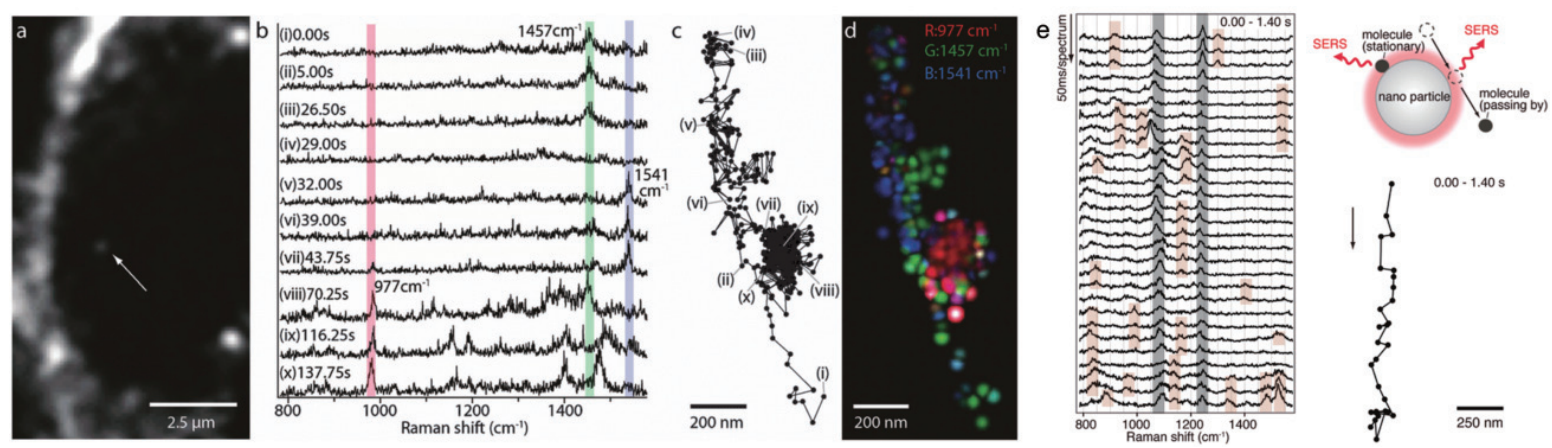

그림 19. (a) Gold 나노입자가 들어간 대식구 세포(Macrophage cell)의 Dark-field 사진, (b) 시간(0 137.75초)에 따른 대식구 세포안의 금 나노입자로부터 검출된 SERS 스펙트럼; $977 \mathrm{~cm}^{-1}$ (Phosphate기의 진동 모드), $1457 \mathrm{~cm}^{-1}\left(\mathrm{CH}_{2}\right.$ 및 $\mathrm{CH}_{3}$ 의 진동 모드), $1541 \mathrm{~cm}^{-1}(A \mathrm{mide}$ $\|$ 의 진동 모드), (c) Dark-field 현미경으로 추적한 시간에 따른 대식구 세포안의 금나노입자 이동 결과, (d) 대식구 세포안의 금나노 입자 이동에 따른 SERS 신호를 컬러맵핑한 결과; 녹색 및 파란색은 직선 이동, 붉은색은 랜덤 이동을 의미함, (e) 시간(0 1.40초) 에 따른 대식구 세포안의 금나노입자로부터 검출된 SERS 스펙트럼; Gold 나노입자 표면에 결합한 바이오 분자에 의한 SERS 신호 $\left(1075 \mathrm{~cm}^{-1}\right.$ 와 $\left.1236 \mathrm{~cm}^{-1}\right)$ 는 시간이 지나도 그대로 나타나는 반면 Gold 나노입자의 Hot-spots에 근접하여 지나가는 바이오 분지들에 의한 SERS 신호는 사라지는 것을 확인할 수 있음. (출처 : 참고문헌 86)

만 진동 주파수의 간섭이 없는 SERS 다중 세포 영상을 얻는데 성공하였다. ${ }^{84}$

그림 18은 D. Radziuk 그룹에 의하여 Label-free SERS 방법을 이용하여 섬유아세포(Fibroblast cell)를 분석한 결과이다. 이들은 Hot-spots의 면적을 넓히고 강화시키기 위해서 Silica 마이크로 입자 표면에 Hot- spots을 갖는 Polyacrylic acid(PAA)가 코팅된 Ag 이량 체들을 코팅하였다.

이러한 마이크로-나노 복합체는 세포안에 들어갔을 때 다양한 생체분자들과 결합하면서 SERS 신호를 발생 할 수 있는데 이를 Hypercluster analysis(HCA)를 통해 시각화 하였다. ${ }^{85)}$
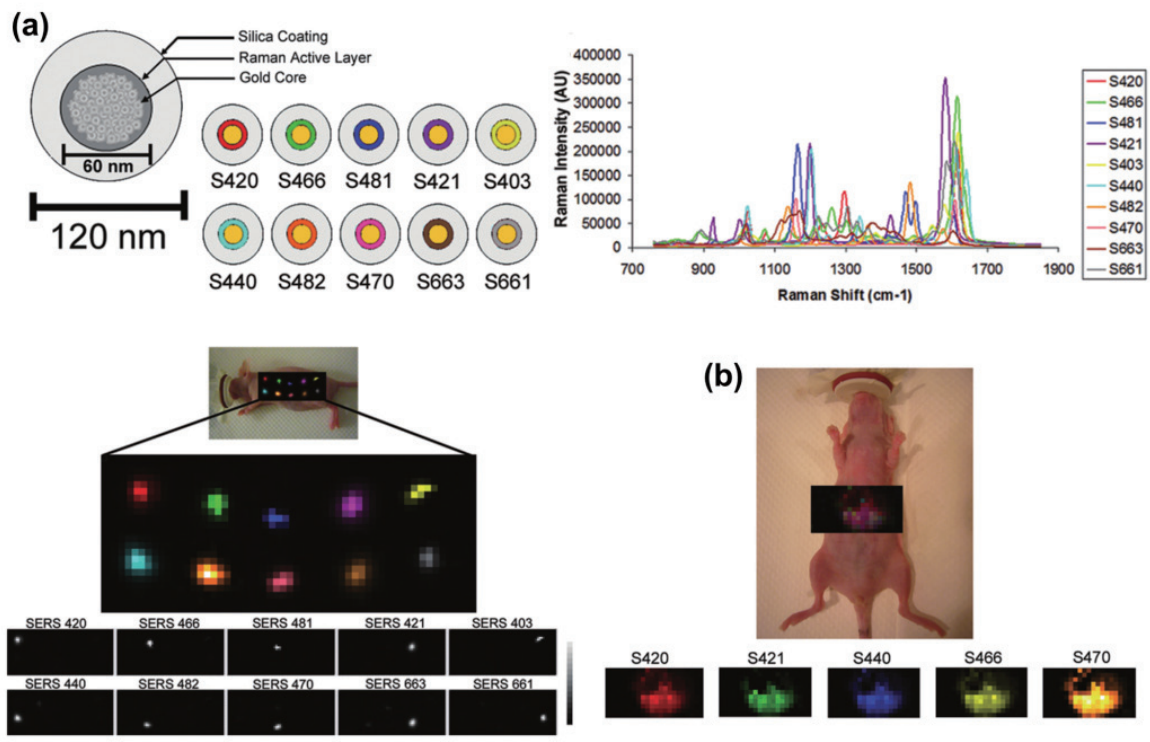

그림 20. (a) In-vivo SERS 이미징 용 Au@SiO 2 core@shell 나노복합체의 모식도, Reporter 종류에 따른 SERS 스펙트럼 및 이를 이용한 In-vivo 다중 SERS 이미지, (b) 간(Liver)에 들어간 5종의 다른 Reporter를 함유한 Au@SiO 2 나노복합체를 이용한 다중 SERS 이미 지. (출처 : 참고문헌 87) 


\section{바이오 물질 분석을 위한 금속 나노입자를 이용한 SERS 분석 연구동향}

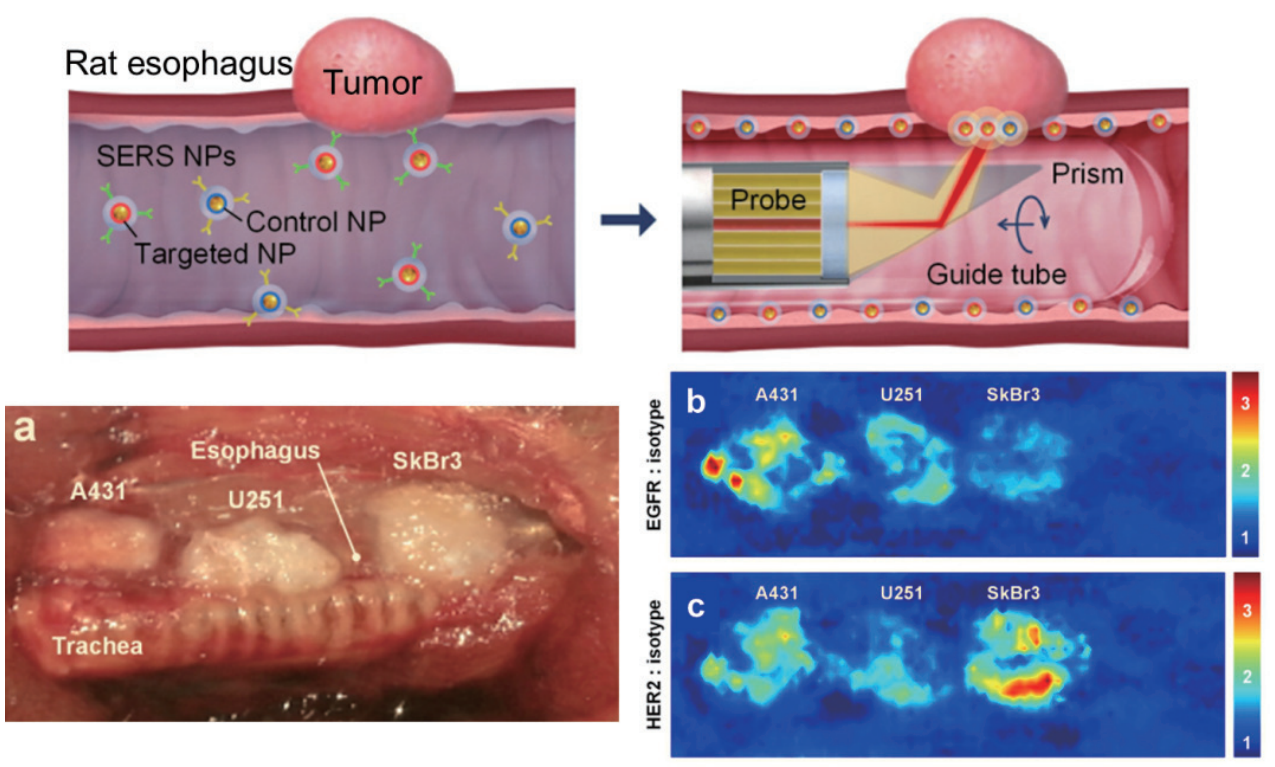

그림 21. SERS 내시경을 이용한 암 진단에 대한 모식도 및 (a) 쥐 식도 안에 3 종류의 세포(A431 ; EGFR이 과발현 된 사람표피암종(Human epidermoid carcinoma) 세포주, U251; 적당하게 EGFR과 HER2가 발현된 사람 교모세포종(Human glioblastoma) 세포주, SkBr3 ; HER2가 과발현된 사람 유방선암종(Human breast adenocarcinoma) 세포주, 3T3 ; 소량의 EGFR과 HER2가 발현된 정상 마우스 섬 유아세포(Fibroblast))로부터 유도된 암 조직의 사진, 및 (c) EGFR 및 HER2 항체가 결합된 나노입자를 주입 후 SERS 내시경에 의해 얻어진 이미지 결과. (출처 : 참고문헌 88)

S. Kawata 그룹은 대식세포(Macrophage cell)안에 서 Gold 나노입자가 이동하면서 Hot-spots안에 들어오 는 다양한 생체분자들의 SERS 신호를 통해 나노입자의 움직임을 실시간으로 관찰하였다(그림 19). ${ }^{86)}$

\section{(5) In-vivo SERS 이미징}

하나의 생체 분자까지도 검출이 가능한 SERS의 고해 상도로 인해 이를 이용한 비침습적 의학 진단 장비를 개 발하려는 많은 연구들이 있어왔다. S. S. Gambhir 그룹 은 그림 20과 같이 $\mathrm{Au} @ \mathrm{SiO}_{2}$ core@shell 나노 구조체 안에 10종의 Reporter를 넣어 동물모델에서 다중 SERS 이미징을 얻는데 성공하였으며 SERS 나노구조체를 Intravenous(IV) injection 시켜 간(Liver)과 같이 생체 안쪽에 위치한 장기에서도 다중 SERS 이미징을 얻는데 성공 하였다. ${ }^{87)}$

그러나 SERS 이미징 기술은 여기 광원의 투과율이 낮 기 때문에 실제 인체에 적용하였을 때 인체 안쪽에 위치 한 장기들을 이미징 하는 것이 쉽지않다. 이러한 문제점 을 극복하기 위해서 J. Liu 그룹은 그림 21과 같이 라만
내시경을 고안하여 In-vivo에서 암 조직에 대한 SERS 이미징을 얻는데 성공하였다. ${ }^{88)}$

\section{2. 결론}

1974년 SERS 현상이 처음으로 발견된 이후로 나노기 술을 바탕으로 한 다양한 분석기술들이 발전해 왔으며 이 를 활용하여 바이오 분야에서 생체분자들의 관찰이 용이 해 졌다. 또한, 각종 질병을 진단하기 위한 비침습적 의 학 진단기기로의 활용 가능성도 매우 높아져 있다. 그러 나 실제 임상에 적용하기에 앞서 SERS 분석 방법에 대한 신뢰성을 더욱 향상시키기 위해서는 다음과 같은 의문점 들을 지속적으로 해결해 나가야한다.

- Label-free SERS 분석을 위해서는 타깃 생체분자 가 나노입자와 만났을 때 화학결합을 통해 나노입자 표면에 단단히 고정되어야 한다. 이로 인해 생물학적 시스템에 적용하였을 때 나노입자들이 타깃 생체분 자와 유사한 다른 분자들과의 결합을 통해 생물학적 과정을 방해 할 가능성은 없는가? 
- 생물학적 시스템에서 어떤 생체 분자들이 SERS로 검 출 가능한가? 또한, 발색단이 없는 생체분자들은 어 떻게 SERS로 검출할 것인가?

- 나노복합체의 혈액순환시간(Blood circulation time)을 증가시키기 위해서 혈액 내 존재하는 다양한 바이오 물질들이 결합하지 못하도록 Antibiofouling agents(e.g. polyethylene glycol)를 결 합시키게 되는데 이는 역으로 SERS 분석 물질이 나 노구조체의 Hot-spots에 접근하는 것을 방해하게 된다. 혈액순환시간을 늘리면서도 선택적으로 SERS 분석 물질을 Hot-spots에 결합시킬 방법이 있는가? 즉, 생물학적 시스템에서 나노입자가 타깃 분자가 아 닌 다양한 생체분자들과의 물리/화학적으로 결합하 는 것을 어떻게 회피 할 것인가?

- 광원을 사용해야 하는 SERS 특성상 실제 임상에서 어디까지 적용 가능한가? 광원이 갖는 고유한 한계점 을 어떻게 극복할 것인가?

- 생물학적 시스템에서 SERS 신호가 시간에 따라 변하 는 문제를 해결 할 수 있는가?

\section{참고문헌}

1. M. Fleischmann, P. J. Hendra, and A. J. McQuillan, "Raman spectra of pyridine adsorbed at a silver electrode," Chem. Phys. Lett., 26 [2] 163-166 (1974).

2. M. Moskovits, "Surface roughness and the enhanced intensity of Raman scattering by molecules adsorbed on metals," J. Chem. Phys., 69 [9] 4159-4161 (1978).

3. M. Moskovits, "Surface-enhanced spectroscopy," Rev. Mod. Phys., 57 [3] 783-826 (1985).

4. J. A. Creighton, C. G. Blatchford, and M. G. Albrecht, "Plasma resonance enhancement of Raman scattering by pyridine adsorbed on silver or gold sol particles of size comparable to the excitation wavelength" J. Chem. Soc., Faraday Trans. 2, 75, $790-798(1979)$.

5. Y. J. Chen, W. P. Chen, and E. Burstein, "Surfaceelectromagnetic-wave-enhanced Raman scattering by overlayers on metals", Phys. Rev. Lett., 36 [20], $1207-1210$ (1976).

6. R. Dornhaus, R. E. Benner, R. K. Chang, and I. Chabay, "Surface plasmon contribution to SERS",
Surf. Sci., 101 [1-3], $367-373$ (1980).

7. B. Pettinger, U. Wenning, and H. Wetzel, " Surface plasmon enhanced Raman scattering frequency and angular resonance of Raman scattered light from pyridine on $\mathrm{Au}, \mathrm{Ag}$ and $\mathrm{Cu}$ electrodes", Surf. Sci., 101[1-3], 409- 416 (1980).

8. J. C. Tsang, J. R. Kirtley, and T. N. Theis, "Surface plasmon polariton contributions to strokes emission from molecular monolayers on periodic Ag surfaces", Solid State Com., 35 [9], 667 - 670 (1980).

9. J. I. Gersten, "The effect of surface roughness on surface enhanced Raman scattering", J. Chem. Phys., 72 [10], $5779-5780$ (1980).

10. J. Gersten, and A. Nitzan, "Electromagnetic theory of enhanced Raman scattering by molecules adsorbed on rough surfaces", J. Chem. Phys., 73 [7], 3023-3037.

11. S. L. McCall, and P. M. Platzman, "Raman scattering from chemisorbed molecules at surfaces", Phys. Rev. B: Condens. Matter Mater. Phys., 22 [4], 1660-1662.

12. M. Kerker, Acc. Chem. Res., "Electromagnetic model for surface-enhanced Raman scattering (SERS) on metal colloids", 17 [8], 271-277 (1984).

13. H. Metiu, and P. Das, "The electromagnetic theory of surface enhanced spectroscopy", Annu. Rev. Phys. Chem., 35, 507-536 (1984).

14. G. C. Schatz, "Theoretical studies of surface enhanced Raman scattering”, Acc. Chem. Res., 17 [10], $370-$ 376 (1984).

15. S. - Y. Ding, E. - M. You, Z. - Q. Tian, and M. Moskovits, "Electromagnetic theories of surfaceenhanced Raman spectroscopy", Chem. Soc. Rev., 46, 4042-4076 (2017).

16. K. Kneipp, Y. Wang, H. Kneipp, L. T. Perelman, I. Itzkan, R. R. Dasari, and M. S. Feld, "Single molecule detection using surface enhanced Raman scattering (SERS)", Phys. Rev. Lett., 78 [9], 1667-1670 (1997).

17. S. Nie, and S. R. Emory, "Probing single molecules and single nanoparticles by surface-enhanced Raman scattering", Science, 275 [5303], 1102-1106 (1997).

18. D. S. Grubisha, R. J. Lipert,; H.-Y. Park, J. Driskell, and M. D. Porter, "Femtomolar detection of prostatespecific antigen: an immunoassay based on surfaceenhanced Raman scattering and immunogold labels", Anal. Chem., 75 [21], 5936-5943 (2003).

19. X. Li, S. Ye, and X. Luo, "Sensitive SERS detection of miRNA via enzyme-free DNA machine signal amplification" Chem. Com, 52 [67], 10269-10272 
(2016).

20. C. Jiang, R. Liu, G. Han, and Z. Zhang, "A chemically reactive Raman probe for ultrasensitively monitoring and imaging the in vivo generation of femtomolar oxidative species as induced by antitumor drugs in living cells" Chem. Com., 49 [59], 6647-6649 (2013).

21. G. McNay, D. Eustace, W. E. Smith, K. Faulds, and D. Graham, "Surface-enhanced Raman scattering (SERS) and surface-enhanced resonance Raman scattering (SERRS): a review of applications", Appl. Spect., 65 [8], 825-837 (2011).

22. S. Schluecker, "Surface-enhanced Raman spectroscopy: concepts and chemical applications", Angew. Chem., Int. Ed, 53 [19], 4756 $\square 4795$ (2014).

23. R. L. McCreery, "Raman spectroscopy for chemical analysis", Vol. 157, Ed. By J. D. Winefordner, John Wiley \& Sons, Inc. Pub. Press., New York, NY, USA, 2000.

24. D. A. Long, "The Raman effect : a unified treatment of the theory of Raman scattering by molecules", John Wiley \& Sons, Inc. Pub. Press., New York, NY, USA, 2002.

25. D. Tuschel, "Raman thermometry", Spectroscopy, 31 [12], 8-13 (2016).

26. R. Meier, and B. Kip, "Determination of the local temperature at a sample during Raman experiments using stokes and anti-stokes Raman bands", Appl. Spect, 44 [4], $707-711$ (1990).

27. R. Meier, and B. Kip, "Determination of the local temperature at a sample during Raman experiments using stokes and anti-stokes Raman bands", Appl. Spect., 44 [4], $707-711$ (2000).

28. R. Aroca, "Surface-enhanced vibrational spectroscopy", John Wiley \& Sons, Inc. Pub. Press., New York, NY, USA, 2006.

29. R. Pilot, R. Signorini, C. Durante, L. Orian, M. Bhamidipati, and L. Fabris, "A review on surfaceenhanced Raman scattering” Biosensors, 9 [57], 1-99 (2019).

30. C. Zong, M. Xu, L. - J. Xu, T. Wei, X. Ma, X. -S. Zheng, R. Hu, and B. Ren, "Surface-enhanced Raman spectroscopy for bioanalysis: reliability and challenges", Chem. Rev., 118 [10], 4946-4980 (2018).

31. R. Pilot, R. Signorini, and L. Fabris, "Surfaceenhanced Raman spectroscopy: principles, substrates, and applications" pp. 89-164 in Metal nanoparticles and clusters: Advances in synthesis, properties and applications, By F. L. Deepak Ed., Springer Press, Cham, Switzerland, 2018.

32. P. G. Etchegoin, and E. C. Le Ru, "A perspective on single molecule SERS: Current status and future challenges" Phys. Chem. Chem. Phys., 10 [40], 6079-6089(2008).

33. K. C. Bantz, A. F. Meyer, N. J. Wittenberg, H. Im, Ö. Kurtuluş, S. H. Lee, N. C. Lindquist, S. - H. Oh, and C. L. Haynes, "Recent progress in SERS biosensing" Phys. Chem. Chem. Phys. 13 [24], 11551-11567 (2011).

34. E. C. Le Ru, C. Galloway, P. G. Etchegoin, "On the connection between optical absorption/extinction and SERS enhancements", Phys. Chem. Chem. Phys., 8 [26], 3083-3087 (2006).

35. A. Otto, "The "chemical" (electronic) contribution to surface-enhanced Raman scattering", J. Raman Spect., 36 [6-7], 497 - 509 (2005).

36. L. A. Dick, A. D. McFarland, C. L. Haynes, and R. P. Van Duyne, "Metal film over nanosphere (MFON) electrodes for surface-enhanced Raman spectroscopy (SERS): Improvements in surface nanostructure stability and suppression of irreversible loss", J. Phys. Chem. B, 106 [4], 853-860 (2002).

37. J. R. Lombardi, and R. L. Birke, "A unified view of surface-enhanced Raman scattering", Acc. Chem. Res., 42, $734-742$ (2009).

38. S. -Y. Ding, J. Yi, J.-F. Li, B. Ren, D.-Y. Wu, R. Panneerselvam, and Z.-Q. Tian, "Nanostructurebased plasmon-enhanced Raman spectroscopy for surface analysis of materials", Nat. Rev. Mater., 1, 16021 (2016).

39. E. C. Le Ru, and P. Etchegoin, "Principles of surface enhanced Raman spectroscopy", Elsevier Sci. Press, Amsterdam, The Netherlands, 2009.

40. M. J. Mulvihill, X. Y. Ling, J. Henzie, and P. Yang, "Anisotropic etching of silver nanoparticles for plasmonic structures capable of single-particle SERS", J. Am. Chem. Soc., 132 [1], $268-274$ (2010).

41. M. D. Sonntag, J. M. Klingsporn, A. B. Zrimsek, B. Sharma, L. K. Ruvuna, and R. P. Van Duyne, "Molecular plasmonics for nanoscale spectroscopy", Chem. Soc. Rev., 43 [4], 1230-1247 (2014).

42. C. E. Talley, J. B. Jackson, C. Oubre, N. K. Grady, C. W. Hollars, S. M. Lane, T. R. Huser, P. Nordlander, and N. J. Halas, "Surface-enhanced Raman scattering from individual au nanoparticles and 
nanoparticle dimer substrates", Nano Lett., 5 [8], $1569-1574$ (2005).

43. J. M. McLellan, A. Siekkinen, J. Chen, and Y. Xia, "Comparison of the surface-enhanced Raman scattering on sharp and truncated silver nanocubes", Chem. Phys. Lett., 427 [1-3], 122-126 (2006).

44. B. J. Wiley, Y. Chen, J. M. McLellan, Y. Xiong, Z.-Y. Li, D. Ginger, and Y. Xia, "Synthesis and optical properties of silver nanobars and nanorice", Nano Lett., 7 [4], $1032-1036$ (2007).

45. J. Fang, S. Liu, and Z. Li, "Polyhedral silver mesocages for single particle surface-enhanced Raman scattering-based biosensor", Biomaterials, 32 [21], $4877-4884$ (2011).

46. M. Rycenga, M. H. Kim, P. H. C. Camargo, C. Cobley, Z. -Y. Li, and Y. Xia, "Surface-enhanced Raman scattering: Comparison of three different molecules on single-crystal nanocubes and nanospheres of silver", J. Phys. Chem. A, 113 [16], 3932-3939 (2009).

47. J. -F. Li, Y. -J. Zhang, S. -Y. Ding, R. Panneerselvam, and Z. -Q. Tian, "Core-shell nanoparticle-enhanced Raman spectroscopy”, Chem. Rev., 117 [7], $5002-5069$ (2017).

48. R. M. Stöckle, Y. D. Suh, V. Deckert, and R. Zenobi, "Nanoscale chemical analysis by tip-enhanced Raman spectroscopy”, Chem. Phys. Lett., 318 [1-3], $131-136$ (2000).

49. M. S. Anderson, "Locally enhanced Raman spectroscopy with an atomic force microscope", Appl. Phys. Lett., 76 [21], 3130 - 3132 (2000).

50. N. Hayazawa, Y. Inouye, Z. Sekkat and S. Kawata, "Metallized tip amplification of near-field Raman scattering", Opt. Commun., 183 [1-4], 333-336 (2000).

51. B. Pettinger, G. Picardi, R. Schuster and G. Ertl, "Surface enhanced Raman spectroscopy: Towards single molecule spectroscopy”, Electrochem., 68 [12], $942-949$ (2000).

52. L. Meng, T. X. Huang, X. Wang, S. Chen, Z. Yang, and B. Ren, "Gold-coated AFM tips for tip-enhanced Raman spectroscopy: theoretical calculation and experimental demonstration", Optics Express, 23 [11], $13804-13813$ (2015).

53. N. Kazemi-Zanjani, S. Vedraine, and F. LagugneLabarthet, "Localized enhancement of electric field in tip-enhanced Raman spectroscopy using radially and linearly polarized light”, Optics Express, 21 [21], 25271- 25276 (2013).

54. J. F. Li, Y. F. Huang, Y. Ding, Z. L. Yang, S. B. Li, X. S. Zhou, F. R. Fan, W. Zhang, Z. Y. Zhou, D. Y. Wu, B. Ren, Z. L. Wang, and Z. Q. Tian, "Shell-isolated nanoparticle-enhanced Raman spectroscopy", Nature, 464 [7287], 392 - 395 (2010).

55. J. -F. Li, S. -Y. Ding, Z. -L. Yang, M. -L. Bai, J. R. Anema, X. Wang, A. Wang, D. -Y. Wu, B. Ren, S. -M. Hou, T. Wandlowski, and Z. -Q. Tian, "Extraordinary Enhancement of Raman Scattering from Pyridine on Single Crystal Au and Pt Electrodes by Shell-Isolated Au Nanoparticles", J. Am. Chem. Soc., 133 [40], $15922-15925$ (2011).

56. Y. -F. Huang, C. -Y. Li, I. Broadwell, J. -F. Li, D. -Y. Wu, B. Ren, and Z. -Q. Tian, "Shell-isolated nanoparticle-enhanced Raman spectroscopy of pyridine on smooth silver electrodes", Electrochim. Acta, 56 [28], $10652-10657$ (2011).

57. S. -Y. Ding, J. Yi, J. -F. Li, and Z.-Q. Tian, "A theoretical and experimental approach to shellisolated nanoparticle-enhanced Raman spectroscopy of single-crystal electrodes", Surf. Sci., 631, 73-80 (2015).

58. D. P. Butcher, S. P. Boulos, C. J. Murphy, R. C. Ambrosio, and A. A. Gewirth, "Face-dependent shell-isolated nanoparticle enhanced Raman spectroscopy of $2,2^{\prime}$-bipyridine on $\mathrm{Au}(100)$ and $\mathrm{Au}(111)$ ", J. Phys. Chem. C, 116 [8], 5128-5140 (2012).

59. N. R. Honesty, and A. A. Gewirth, "Shell-isolated nanoparticle enhanced Raman spectroscopy (SHINERS) investigation of benzotriazole film formation on $\mathrm{Cu}(100), \mathrm{Cu}(111)$, and $\mathrm{Cu}($ poly)", $J$. Raman Spectrosc., 43 [1], 46 - 50 (2012).

60. A. V. Rudnev, A. Kuzume, Y. Fu, and T. Wandlowski, "CO oxidation on $\mathrm{Pt}(100)$ : New insights based on combined voltammetric, microscopicand spectroscopic experiments", Electrochim. Acta, 133, 132-145 (2014).

61. C. -Y. Li, J. -C. Dong, X. Jin, S. Chen, R. Panneerselvam, A. V. Rudnev, Z.-L. Yang, J.-F. Li, T. Wandlowski, and Z.-Q. Tian, "In situ monitoring of electrooxidation processes at gold single crystal surfaces using shell-isolated nanoparticle-enhanced Raman spectroscopy", J. Am. Chem. Soc., 137 [24], $7648-7651$ (2015).

62. A. Bonifacio, S. Cervo, and V. Sergo, "Label-free 
surface-enhanced Raman spectroscopy of biofluids: Fundamental aspects and diagnostic applications", Anal. Bioanal. Chem., 407 [27], 8265 - 8277 (2015).

63. S. Ma, Q. Li, Y. Yin, J. Yang, and D. Liu, "Interference-free surface enhanced Raman scattering tags for single-cell molecular imaging with a high signal-to-background ratio", Small, 13 [15], 1603340 (2017).

64. N. M. S. Sirimuthu, "Investigation of the stability of labelled nanoparticles for SE(R) RS measurements in cells" Chem. Com., 47 [14], 4099-4101 (2011).

65. Y. Yin, Q. Li, S. Ma, H. Liu, B. Dong, J. Yang, and D. Liu, "Prussian blue as a highly sensitive and background-free resonant Raman reporter", Anal. Chem., 89[, 1551-1557 (2017).

66. K. V. Kong, Z. Lam, W. D. Goh, W. K. Leong, and M. Olivo, "Metal carbonyl-gold nanoparticle conjugates for live-cell SERS imaging", Angew. Chem., Int. Ed., 51 [3], 9796-9799 (2012).

67. Z. -L. Song, Z. Chen, X. Bian, L. -Y. Zhou, D. Ding, H. Liang, Y. -X. Zou, S. -S. Wang, L. Chen, C. Yang, X. -B. Zhang, and W. Tan, "Alkynefunctionalized superstable graphitic silver nanoparticles for Raman imaging", J. Am. Chem. Soc., 136 [39], 13558-13561 (2014).

68. S. Habuchi, and J. Hofkens, "Single-molecule surface-enhanced resonance Raman spectroscopy of the enhanced green fluorescent protein EGFP", Surf. Enhanced Raman Scattering, 103, 297 - 312 (2006).

69. K. Singhal and A. K. Kalkan, "Surface-enhanced Raman scattering captures conformational changes of single photoactive yellow protein molecules under photoexcitation", J. Am. Chem. Soc., 132 [2], 429431 (2010).

70. H. Xu, E. J. Bjerneld, M. Käll and L. Börjesson, "Spectroscopy of single hemoglobin molecules by surface enhanced Raman scattering", Phys. Rev. Lett., 83 [21], 4357 - 4360 (1999).

71. X. X. Han, G. G. Huang, B. Zhao and Y. Ozaki, "Label-free highly sensitive detection of proteins in aqueous solutions using surface-enhanced Raman scattering”, Anal. Chem., 81 [9], 3329 - 3333 (2009).

72. I. Bruzas, W. Lum, Z. Gorunmez, and L. Sagle, "Advances in surface-enhanced Raman spectroscopy (SERS) substratesfor lipidand proteincharacterization: sensing and beyond", Analyst, 143 [17], 3990-4008 (2018).
73. A. Rygula, K. Majzner, K. M. Marzec, A. Kaczor, M. Pilarczyk, and M. Baranska, "Raman spectroscopy of proteins: a review", J. Raman Spect., 44 [8], 10611076 (2013).

74. K. Czamara, K. Majzner, M. Z. Pacia, K. Kochan, A. Kaczor, and M. Baranska, "Raman spectroscopy of lipids: a review", J. Raman Spect., 46 [1], 4-20 (2015).

75. T. Brulé, H. Yockell-Lelièvre, A. Bouhélier, J. Margueritat, L. Markey, A. Leray, A. Dereux, and E. Finot, "Spectral pointillism of enhanced Raman scattering for accessing structural and conformational information on single protein", J. Phys. Chem. C, 118 [1], 17975 - 17982 (2014).

76. T. Brulé, A. Bouhelier, A. Dereux, and E. Finot, "Discrimination between single protein conformations using dynamic SERS”, ACS Sens., 1 [6], 676-680 (2016).

77. L. -J. Xu, Z. -C. Lei, J. Li, C. Zong, C. J. Yang, and B. Ren, "Label-free surface-enhanced Raman spectroscopy detection of DNA with single-base sensitivity”, J. Am. Chem. Soc., 137 [15], 5149-5154 (2015).

78. L. - J. Xu, C. Zong, X. - S. Zheng, P. Hu, J. - M. Feng, and B. Ren, "Label-free detection of native proteins by surface-enhanced Raman spectroscopy using iodide-modified nanoparticles", Anal. Chem., 86 [4], 2238-2245 (2014).

80. L. Guerrini, Ž. Krpetic' , D. van Lierop, R. A. Alvarez-Puebla, and D. Graham, "Direct surfaceenhanced Raman scattering analysis of DNA duplexes", Angew. Chem., Int. Ed., 54 [4], 1144-1148 (2015).

81. E. Garcia-Rico, R. A. Alvarez-Puebla, and L. Guerrini, "Direct surface-enhanced Raman scattering (SERS) spectroscopy of nucleic acids: from fundamental studies to real-life applications", Chem. Soc. Rev., 47 [13], 4909-4923, 2018.

82. E. Papadopoulou, and S. E. J. Bell, "Label-free detection of nanomolar unmodified single- and double-stranded DNA by using surface-enhanced Raman spectroscopy on Ag and Au colloids", Chem. - Eur. J., 18 [17], 5394 - 5400 (2012).

83. Y. Yin, Q. Li, S. Ma, H. Liu, B. Dong, J. Yang, and D. Liu, "Prussian blue as a highly sensitive and background-free resonant Raman reporter", Anal. Chem., 89 [3], 1551-1557 (2017). 
84. Y. Chen, J. -Q. Ren, X. -G. Zhang, D. -Y. Wu, A. -G. Shen, and J. -M. Hu, "Alkyne-modulated surface-enhanced Raman scattering-palette for optical interference-free and multiplex cellular imaging", Anal. Chem., 88 [12], 6115-6119 (2016).

85. D. Radziuk, R. Schuetz, A. Masic, and H. Moehwald, "Chemical imaging of live fibroblasts by SERS effective nanofilm", Phys. Chem. Chem. Phys., 16 [44], 24621-24634 (2014).

86. J. Ando, K. Fujita, N. I. Smith, and S. Kawata, "Dynamic SERS imaging of cellular transport pathways with endocytosed gold nanoparticles",
Nano Lett., 11 [12], 5344 - 5348 (2011).

87. C. L. Zavaleta, B. R. Smith, I. Walton, W. Doering, G. Davis, B. Shojaei, M. J. Natan, and S. S. Gambhir, "Multiplexed imaging of surface enhanced Raman scattering nanotags in living mice using noninvasive Raman spectroscopy”, PNAS, 106 [32], 13511-13516 (2009).

88. Y. W. Wang, S. Kang, A. Khan, P. Q. Bao, and J. T. C. Liu, "In vivo multiplexed molecular imaging of esophageal cancer via spectral endoscopy of topically applied SERS nanoparticles", Biomed. Opt. Express, 6 [10], 3714-3723 (2015).

\section{๑. 장 의 순}

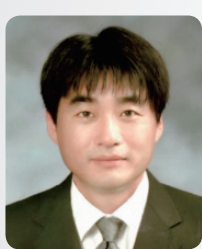

20 2004년 서울대학교 화학과 박사

○ 2004년 포항공과대학교 신소재공학과 박사후 연구원

- 2005년 KT 미래기술연구소 선임연구원

( 2008년 미국 스탠포드대학교 의과대학 방사선과 박사 후 연구원

○ 2010년 금오공과대학교 응용화학과 부교수 